\title{
Mother's Participation in Literacy Education of Children with Special Learning Disability: A Draft Training Program?
}

\author{
Assist. Prof. Dr. Didem Kayahan Yüksel \\ Cumhuriyet University- Turkey \\ ORCID: 0000-0002-0184-6070 \\ didemkayahan@cumhuriyet.edu.tr
}

\author{
Assoc. Prof. Dr. Esma Emmioğlu Sarıkaya \\ Gaziosmanpaşa University- Turkey \\ ORCID: 0000-0002-6188-7173 \\ esma.emmioglu@gop.edu.tr
}

\begin{abstract}
The aim of this study is to propose a draft education program for mothers to support the participation of mothers in the literacy education process of children with special learning disability and to examine the results of the application by applying the draft program. Qualitative data collection methods such as interview, observation, researcher diary was used in the study, which was designed as a program development research. The participants of the study were determined by using criterion sampling, one of the purposive sampling methods and four children with special learning disability are their mothers and teachers. In the analysis of the obtained data, descriptive analysis was performed using the MAXQDA qualitative data analysis program. In order to ensure validity and reliability in the study; data diversity, expert review, long-term interaction, purposive sampling and detailed description methods were used. The content of the draft mother education program involves special learning disabilities, teaching principles, literacy, preparation for literacy, teaching reading and writing. The lectures as a teaching strategy was adopted in the mother education program. Question-answer, discussion, narration, case study and role playing methods were used as instructional methods. In the evaluation dimension of the program, the process evaluation and total evaluation activities were included. At the end of each teaching session there were evaluation activities such as open-ended questions, gap filling, accuratefalse marking, fishbone, diagnostic branched tree, self-evaluation. Based on the participant's statements in the study, the draft of the mother education program; It is thought that mothers have positive contributions in terms of cooperation with the teacher, better communication with the child and the teacher, and having their child do homework/repeat at home. In addition, the participating teachers stated that there were positive changes in the motivation of mothers and children, and that mothers took a more active role and responsibility in the education of their children. Based on the observation findings, it is thought that the draft mother education program has positive reflections on mother-child literacy studies.
\end{abstract}

Keywords: Education Program Draft, Family Participation in Education, Literacy Education, Mother Education, Special Learning Disability.

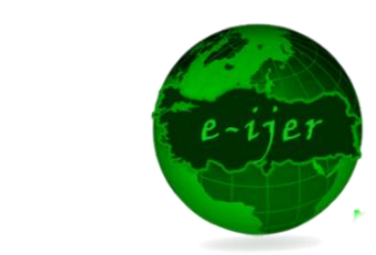

E-International Journal of Educational Research

Vol: 12, No: 5, pp. 36-64

Research Article

Received : 2021.09.22 Accepted : 2021.11 .08

\section{Suggested Citation}

Kayahan- Yüksel, D. \& Emmioğlu- Sarıkaya, E. (2021). Mother's participation in literacy education of children with special learning disability: a draft training program, E-International Journal of Educational Research, 12(5), 36-64. DOI: https://doi.org/10.19160/e-ijer.999351

\footnotetext{
${ }^{1}$ This research has been produced from the first author's doctoral thesis titled "Özel Öğrenme Güçlüğü Yaşayan Çocukların Okuma Yazma Eğitimine Anne Katılımı: Bir Eğitim Programı Taslağı" prepared under the supervision of the second author.
} 


\section{INTRODUCTION}

Reading and writing skills are among the basic academic skills. Children who cannot learn to read and write at the same time as their peers may experience some disability in terms of both academic and social behaviors. Children with special learning disability have difficulty in learning skills related to many lessons, especially Turkish. Learning disability experienced in one or more areas negatively affect the child's learning of other skills and social and social adaptation. Children with learning disabilities can learn academic skills similar to their peers, when necessary, support is provided. What is important here is the provision of appropriate support services to the child and family. Studies show that children with learning disabilities can learn to read and write when the necessary support and help is provided (Akyol \& Yıldız, 2010; Duran \& Sezgin, 2012). When the literature is examined, it has been seen that different methods and techniques are used in the literacy education of children with learning difficulties. Roberts, Torgesen, Boardman, and Scammacca (2008) developed a five-step strategy to overcome reading difficulties in students with learning disabilities. These; vocabulary work, fluency exercises, vocabulary exercises, comprehension exercises and motivation. Chard, Vaughn, and Tyler (2002) included 24 studies in which they examined the effects of models designed to increase reading fluency in students with learning disabilities. According to the results obtained from the research, in providing reading fluency to individuals with learning difficulties; Started reading from familiar texts, repetitive reading, giving feedback during reading and increasing the text difficulty according to performance are effective methods that can be used (Chard, Vaughn, \& Tyler, 2002). Similarly, Özmen (2005) states that students with learning disabilities read the stories and fairy tales they already know faster, therefore, in the process of acquiring fluent reading skills for children with learning difficulties, it is necessary to start with the stories and fairy tales that the student knows. Dağ (2010), on the other hand, in her study conducted with a 5th grade student who has a learning disability in order to overcome her reading difficulties, concluded that the 3P method (pause, prompt, praise) and the gap-filling technique led to progress in the student's reading level. In his research, Görgün (2018) concluded that fluent reading and reading comprehension support education program had a positive effect on the fluent reading and reading comprehension skills of children with special learning difficulties. Kardaş-işler and Şahin (2016), in their research conducted as a student case study on reading and comprehension disorder, concluded that the strategy of listening to the paragraph beforehand and the paired reading strategy led to a decrease in the child's reading errors. Dündar and Akyol (2014), in their study with a student who has reading and comprehension problems, firstly determined the cause of the child's reading errors. As a result of the examinations, it was determined that the child's reading errors were caused by the lack of motivation and an 11-week teaching program was applied to ensure the motivation of the child. In the next stage, in the study in which the repeated reading method was applied, it was concluded that there was an increase in the child's reading skills. Sezgin and Akyol (2015), in their study with a student with reading difficulties, concluded that repetitive reading, paired reading, and reading theater activities had a positive effect on reducing reading errors and increasing the level of reading comprehension. Duran and Sezgin (2012), in their study with a student with reading difficulties, concluded that the guided reading method had a positive effect on the student's word recognition, comprehension and reading aloud skills. Uçar-Rasmussen and Cora-Ince (2017) concluded that the thinking aloud method is effective in teaching metacognitive reading comprehension strategies in their research conducted with three children with special learning difficulties in a single-subject research design.

It is seen that the studies in the literature generally focus on the reading process. On the other hand, Akçin (2009) states that students with learning difficulties usually have spelling mistakes. pre-writing, writing or drafting, reviewing, editing, printing and sharing with the audience emphasizes the use of a model. Yıldız (2013), on the other hand, applied a staged writing instruction action plan from major muscle movements to small muscle movements in a study conducted with a student with writing difficulties. As a result of the application, it was seen that 
there were positive changes in the writing skills of the students. Although various methods and techniques are used in the literacy education process, the use of a single method or technique is recommended (Gersten, Fuchs, Williams, \& Baker, 2001).

Özyürek (2009), in the literacy education process of children with special learning difficulties; It states that it is necessary to make adaptations in teaching methods and materials, to provide students with a successful life, to cooperate with the family, school administration and other teachers in the preparation and implementation of individualized education programs, to ensure the participation of the family in education and to benefit from support education services. for the student to learn. Uçgun (2003) states that the role of the family and the teacher is very important in eliminating learning disabilities and that students with learning disabilities should receive appropriate therapies. Family is the first source structure where education starts and continues (Uluğtekin, Cılga, \& II, 2002). In the pre-modern era, the family, which took on the duties of the child's education, employment and adaptation to social life, transferred a large part of these functions to educational institutions in the modern era, but its continuing impact on the child's education is an undeniable fact (Çağan, 2011; Toprakçı, 2017). The family can participate in their child's education in different ways. The way the family participates in education may change periodically according to the characteristics and needs of the family, child and school. Epstein et al. examined the roles of the family in the child's education and ways of participating in education under six headings. family education; parenting duties, communicating with the school, supporting the school, doing home teaching activities, making decisions about the school and providing cooperation (Henderson \& Mapp, 2002).

Literacy education is a process that usually starts at school and continues in the family. In particular, families of children who need more support and have learning disability should participate in the education of their children (Gül, Yürümez, Gül, Kılıç, \& Günay-Ay, 2016; Özçelik, 1983). Families can participate in the literacy education of their children in different ways. For example, they can help by encouraging their child to read, reading with them, and controlling their daily homework. After their child comes home from school, parents should ask their child about the homework of the day and provide a suitable environment for doing homework (Gül, 2007). Dadandi and Dadandi (2005), in their study with Turkish teachers of children with special learning disability; He emphasized that teachers need family support because the classes are crowded and these children forget what they have learned quickly, but they do not participate in the education of their children due to the fact that the families are ignorant and do not pay enough attention to the education of the children, and even children often return to school without doing their homework.

Legally, according to subparagraph g of Article 4 of the Decree Law No. 573 on Special Education, "It is essential to ensure that families actively participate in all aspects of the special education process." (Özel Eğitim Hakkında Kanun Hükmünde Kararname, 1997). Although families should participate in the education of the child, sometimes families may not have sufficient knowledge and skills about how and in what way they will participate in the education of their children. With the change in education programs over time, families can be caught unprepared for the changes made. In Turkey, in the 2005-2006 academic year, the sentence analysis method was switched to the sound-based sentence method in the first literacy education. This situation made it compulsory for existing classroom teachers to learn the new teaching method, and the Ministry of National Education facilitated the adaptation of teachers to the new method with inservice training activities for this purpose. However, no national training was provided for families to adapt to the new method. It has been observed that some families who encounter a method different from the method in which they learn to read and write have difficulty in guiding their children (Gül, 2007; Ölmez, 2017). In this context, it is thought that the families of children with learning disabilities who are expected to provide special support to their children's education also need training to support their children's first literacy process. 
Children with special learning disability need frequent repetitions and family support in their education. Special education is a teamwork, and the family has to be an active part of this team. The time that the classroom teacher can spare on a daily basis, especially for a child participating in inclusive education, is limited. In this case, it is a need for the family to participate in the education of their child (Başal \& Batu, 2002). Parents need to have knowledge about literacy methods and techniques in order to be able to provide the right help to the child (Gül, 2007). From time to time, classroom teachers offer parents the knowledge and skills related to their participation in their children's education through verbal or written materials. However, trainings that are not prepared and implemented within a program are insufficient. These educational services offered to families should be provided within a program.

Families should be encouraged to participate in their child's education. However, from time to time, families may have insufficient information about their child's participation in education. In these cases, it is necessary to organize family trainings to ensure the participation of the family in education. Family education is the most important support used in the education of individuals with special needs (Tavil \& Karasu, 2013). "Family education is an education that includes all kinds of guidance and counseling services to be given to the family in order to contribute to the education of the individual at all educational levels" (Özel Eğitim Hizmetleri Yönetmeliği, 2018, art. 18). According to the result obtained from his research, Sucuoğlu (1996) emphasizes that families should not be seen as just receiving and giving information, and that families should be seen as active individuals participating in the child's education. Family education can be employed for different purposes and in different ways. However, in order to obtain sufficient efficiency from family education, the knowledge and skills desired to be acquired by the family must be applied within a program.

As would be expected from any formal education process, the education to be offered to families should also be done within a certain program. In this study, a draft education program for mothers was proposed in order to support the participation of mothers in the literacy education process of children with special learning disability, and the results of the application were examined by applying the draft program. In the study, it was aimed that the mother, who is the parent who spends the most time with the child, and her child, who has special learning disability, do more accurate and planned literacy activities together. By using the knowledge and skills acquired during the program in participation in the literacy education of her child, the mother will be able to make her child's homework on literacy more accurate and will be able to repeat the topics that her child has studied at school that day. In this way, it is expected that the child will contribute positively to his literacy skills.

\section{Research Questions}

The aim of this study is to propose a draft education program for mothers in order to support the participation of mothers in the literacy education process of children with special learning disability and to examine the results of the application by applying the draft program.

\section{METHOD}

This study, which was carried out in order to propose a draft education program for mothers in order to support the participation of mothers in the literacy education process of children with special learning disability, and to examine the results of the application by applying the draft program, is a curriculum development research. Curriculum development is a cyclical and dynamic process; therefore, research problems aim to suggest a system instead of reaching generalizations by focusing on a system rather than hypotheses (Ornstein \& Hunkins, 1998; Richey \& Klein, 2005; Varış, 1969). Curriculum development research is a method that examines the consistency and effectiveness of the design, development and evaluation stages of education programs 
(Büyüköztürk, Kılıç- Çakmak, Akgün, Karadeniz, \& Demirel, 2014; Richey, Klein, \& Nelson, 2004; Richey \& Klein, 2005; Varış, 1969).

Curriculum development is a dynamic and cyclical process carried out by many experts in teamwork (Ornstein \& Hunkins, 1998). The mother training program proposed in this study was named as the training program draft because it was the product of a more micro-level study. In the study, a draft education program was prepared in order to support the participation of mothers in the literacy education process of children with special learning disability, and the application results were evaluated by applying the mother education program draft. It is known that qualitative or quantitative data collection methods can be used in the curriculum development process (Richey, Klein, \& Nelson, 2004). In this study, qualitative data collection methods such as interview, observation, researcher's diary, and end-of-session evaluation form were used. The stages of the study are presented in Figure 1.

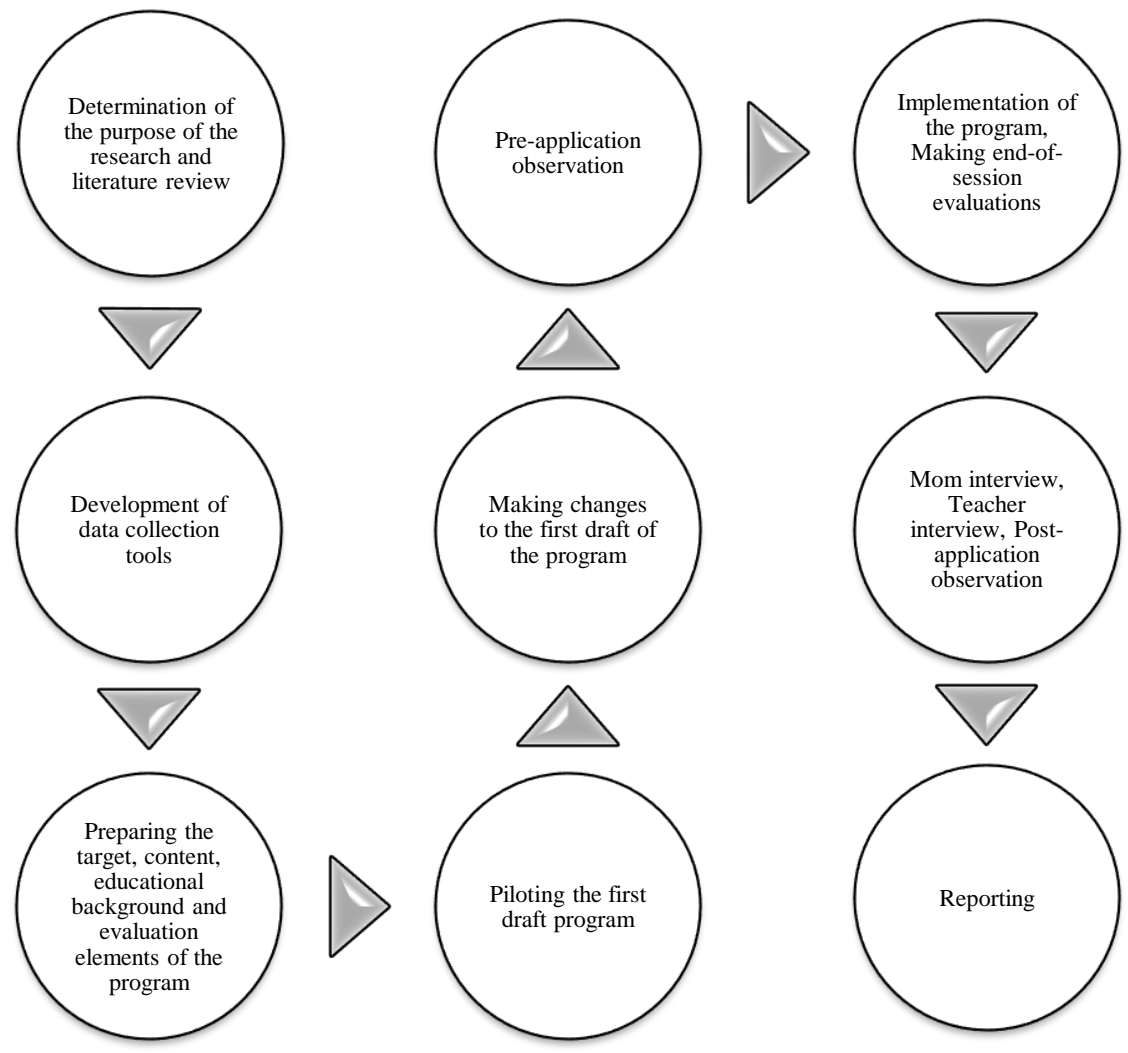

Figure 1. Stages of the Study

This study was carried out in nine stages. In the study, first of all, a literature review was conducted and it was seen that the participation of families in the literacy process and the education of children with special learning disability were emphasized (Akyol \& Yıldız, 2010; Dadandi \& Dadandi, 2005; Dam, 2008; Duran \& Sezgin, 2012; Froiland, Peterson, \& Davison, 2013; Gül, 2007; Gül, Yürümez, Gül, Kılıç \& Günay-Ay, 2016; Miedel \& Reynolds, 1999; Özyürek, 2009; Rasinski \& Stevenson, 2005; Uçgun, 2003). Afterwards, the measurement tools (interview forms, observation form and end-of-session evaluation form) to be used in the research were developed by the researcher. Then, by examining the relevant literature, the preparation of the target, content, educational status, and evaluation items of the mother education program in the literacy education process was done and the preliminary application of the program proposed as the first draft was made. A mother, her child with special learning disability and the child's teacher participated in the pre-application. In the light of the findings obtained from the preliminary application, changes were made in the first draft of the program. In the next stage, the selection of the mothers who will participate in the implementation of the revised mother education 
program draft and the observation of the mother-child literacy studies of the selected participants were carried out. Afterwards, the draft mother education program was implemented with the mothers participating in the study. After the completion of each teaching session during the implementation of the program, the mothers were presented with end-of-session evaluation forms and asked to fill in these forms taking into account the education they attended that day. At the last stage, post-application interviews with mothers and teachers, observation of motherchild literacy studies were carried out and the results were reported.

\section{Participants}

The participants in this study were determined by using the criterion sampling method, one of the purposive sampling methods. Purposeful sampling is a non-random sampling method and allows in-depth analysis by selecting the sample depending on the purpose of the research (Büyüköztürk, Kılıç- Çakmak, Akgün, Karadeniz, \& Demirel, 2014). Criterion sampling, on the other hand, is the study of situations that carry a set of criteria determined previously or determined by the researcher (Yıldırım \& Şimşek, 2013). In this study, the participants; The four children with special learning disability are the mothers of these children and the teachers of these children. Criteria for children participating in this study; The children were diagnosed with a "special learning disability" as a result of the Guidance Research Center (RAM) examination, they do not have any other disability accompanying the special learning disability, they have completed their literacy preparation skills but are illiterate. For participating mothers, the criteria are being the mother of the child participating in the study and being literate because the mother is expected to support her child in literacy. The criterion for participating teachers is that they are teachers of the children participating in the study.

While determining the participants of the study, first of all, a special education center operating in the central district of Sivas province was interviewed; Information about the purpose, scope and process of the study is given. Then, an information notice was posted in the school's entrance-exit locations and parents' room to inform the parents in the institution. In addition, parents were informed about the education by meeting with the guidance teacher of the institution. The name, surname and contact information of all 12 mothers who agreed to participate in the study as a result of the interviews conducted by the counselor were conveyed to the researcher by the counselor. Until this stage, no selection process has been made by the counselor or the researcher. Later, the researcher interviewed individually with all mothers who volunteered to participate in the study. In the preliminary interviews with the mothers who volunteered to participate in the study, three of the mothers had concomitant disabilities because of their children ( 1 child had attention deficit and hyperactivity disorder, 2 children had language and speech disorders); Four of the mothers were not included in the study because they were illiterate. One mother declined to participate in the study due to private reasons. As a result, 4 children with prerequisite characteristics, their mothers and teachers formed the participant group of this study. The participants of the study were informed about the research and the necessary permission was obtained in writing. In order to protect ethical values in the next parts of the study, mothers $M_{1}, M_{2}, M_{3}, M_{4}$; children will be referred to as $C_{1}, C_{2}, C_{3}, C_{4}$ and teachers as $T_{1}, T_{2}, T_{3}, T_{4}$.

Table 1. Demographic Characteristics of Participating Mothers

\begin{tabular}{llll}
\hline Participant Mother & Age & Education Status & Job Status \\
\hline $\mathbf{M}_{\mathbf{1}}$ & 29 & Primary School & Housewife \\
$\mathbf{M}_{\mathbf{2}}$ & 28 & Secondary School & Housewife \\
$\mathbf{M}_{\mathbf{3}}$ & 34 & Primary School & Housewife \\
$\mathbf{M}_{\mathbf{4}}$ & 41 & High School & Housewife \\
\hline
\end{tabular}

It is seen that two of the participating mothers are primary school graduates, one secondary school graduate and one high school graduate. All of the participating mothers aged between 28-41 are housewives. Table 2 presents the demographic information of the participating children. 
Table 2. Demographic Characteristics of Participating Children

\begin{tabular}{llll}
\hline Participant Child & Age & Gender & Education Level \\
\hline $\mathbf{C}_{\mathbf{1}}$ & 6 & Male & Primary School 1st Grade \\
$\mathbf{C}_{\mathbf{2}}$ & 11 & Male & Primary School 4st Grade \\
$\mathbf{C}_{\mathbf{3}}$ & 9 & Male & Primary School 4st Grade \\
$\mathbf{C}_{\mathbf{4}}$ & 9 & Male & Primary School 2st Grade \\
\hline
\end{tabular}

It is seen that the ages of the children who participated in the study ranged from 6 to 11 years. All the children are boys, one of them is the first grade of primary school, one of them is the second grade of primary school and two of them are the fourth-grade students at primary school. Table 3 presents the demographic characteristics of the participating teachers.

Table 3. Demographic Characteristics of Participating Teachers

\begin{tabular}{lllll}
\hline Participating Teacher & Age & Gender & Education Level & $\begin{array}{l}\text { Professional } \\
\text { Experience }\end{array}$ \\
\hline $\mathbf{T}_{\mathbf{1}}$ & & & \\
$\mathbf{T}_{\mathbf{2}}$ & 51 & Female & Classroom Teacher/Undergraduate & 24 Years \\
$\mathbf{T}_{\mathbf{3}}$ & 35 & Male & Special Education Teacher/ Undergraduate & 11 Years \\
$\mathbf{T}_{\mathbf{4}}$ & 40 & Male & Classroom Teacher/ Undergraduate & 15 Years \\
\hline
\end{tabular}

Two of the participating teachers are male and two are female, and their ages range from 35 to 51. Three of the teachers, whose professional experience ranges from 10 to 24 years, are graduates of the classroom teaching undergraduate program and one is a special education teacher graduate.

\section{Data Collection Tools}

In this study, data diversification, which is frequently applied, was used to provide data richness in qualitative research (Johnson, 2014). By combining data diversity and various methods, the reliability of research data is increased (Başkale, 2016; Patton, 2014). Data diversity reveals the innovative aspects of the event as well as obtaining similar and different data in the research (Başkale, 2016). As a data collection tool in this study; semi-structured interview forms, observation form, researcher's diary and end-of-session evaluation form were used.

1. Semi-Structured Interview Forms. Interview is a one-to-one opinion method that is used to reveal the feelings, thoughts and information of the source person (Balcl, 2013; Patton, 2014). The semi-structured interview form, on the other hand, is a data collection tool that includes predetermined open-ended questions and allows changes to be made during the interview (Sönmez \& Alacapınar, 2011). In this study, there are two different semi-structured interview forms: mother interview form and teacher interview form. While developing each form, first, the relevant literature review was made and the forms created by the researcher were sent to a training program, an assessment and evaluation, and a special education field expert to be submitted to expert opinion in order to ensure content validity. Necessary adjustments were made in line with the feedback received from the experts. In order to test the face validity of the forms, the participants of this study were interviewed with people with similar characteristics (a mother with a child with a special learning disability whose child is in the process of literacy education, and a teacher with a student with a special learning disability who works on literacy education with this child). has been applied. As a result of the pilot application, necessary arrangements were made, and the interview forms were finalized.

The mother interview form consists of nine items and probe questions. In the mother interview form, there are questions to determine the effects of the program applied with the mothers on the child, the unforeseen positive and negative outcomes of the program, the mother's participation in education and the mother's satisfaction with the program. The teacher interview form consists of five items and probe questions. In the teacher interview form, there are questions to determine the satisfaction of the teacher with the program, the changes in the 
literacy level of the student, the mother's participation in post-program education and the support received from the mother.

2. Observation Form. Observation is the observation of the environment, situation or people in order to examine the situations and behaviors in a certain environment in detail (Balcl, 2013; Patton, 2014). In the study, observations were made in order to examine the reflections of the mother education program draft on the child's literacy education, and an observation form was prepared in order to collect data on how the mothers reflected the knowledge and skills acquired from the program into practice. In the process of developing the observation form, first, the relevant literature was examined. The 8-item form prepared by the researcher was sent to a training programs, a special education and an assessment and evaluation specialist in order to get expert opinions. In line with the opinions of the experts, necessary adjustments were made in the form. The observation form consists of 13 items. Qualitative data obtained from qualitative research can be digitized for comparison (Yıldııım \& Şimşek, 2013). In this study, the data obtained from the observation forms were converted into numerical expressions by scoring. There are three options, yes, partially, no, showing the realization of the behavior observed in the form. In the observation form, scoring is made as yes $=3$, partially $=2$, no $=1$.

3. Researcher's Diary. In researcher diaries, observations, field notes, tables, exam results, experiences and emotions can be included (Johnson, 2014). The researcher's diary used in this study, during the implementation of the draft mother education program and during the observation of mother-child studies; It includes the observations, experiences, and feelings of the researcher.

4. End of Session Evaluation Form. It is a data collection method used to collect student's feelings, thoughts and ideas about the lesson and the subject learned (Johnson, 2014). In this study, the mother is in the role of the student and the end-of-session evaluation form was used at the end of each teaching session in order to examine the positive/negative situations that emerged during the implementation of the mother education program draft. The end-of-session evaluation form was prepared for the mother under the headings of topics that the mother learned well, learned insufficiently, feelings and experiences.

\section{Data collection procedures}

Before the implementation of the mother participation program, mother-child literacy studies were observed. The observation of mother-child studies was carried out in an individual education classroom in a private education institution. During the observation, no intervention was made in the literacy activities that the mother and child did together, and no time limit was made. During the observation, the mother and child sit opposite each other at the table. The researcher and the second observer recorded the mother-child behaviors through the observation form. The second observer has a bachelor's degree in classroom teaching, completed her master's degree in special education and continues her doctoral education in the same field. The second observer with five years of professional experience is a 30-year-old woman. The second observer filled the observation form independently of the researcher by observing the mother-child behaviors.

In addition, before the implementation of the program, a meeting was held with the mothers who will participate in the implementation. At the meeting, the researcher and participant mothers introduced themselves. Later, the mothers talked about their experiences with their children with special learning disability and their purpose of participating in the program. The meeting lasted 35 minutes. During the implementation of the program, all studies were carried out with mothers, and the researcher did not directly intervene in the literacy education process of children. The mother education program was implemented by the researcher as five sessions in a total of 14 lesson hours, each lesson being 40 minutes, in a special education institution where individuals with special needs receive supportive education. At the end of the teaching sessions, 
the end-of-session evaluation form was filled in individually by the participating mothers. In this process, the researcher did not intervene in the process.

In the study, in order to determine the opinions of mothers and teachers about the draft mother education program in the literacy education process of children with special learning disability, interviews were conducted with the participating mothers and teachers after the program was implemented. Interviews with the mother interview form and the teacher interview form were carried out by the researcher. Post-application interviews with mothers and teachers were held in the counseling room of the special education center where the program was implemented. During the interviews, the researcher and the participant were found one-on-one. The interviews were recorded with a voice recorder and there was no time limit.

In the study, mother-child literacy studies were also observed after the implementation of the program. Observations made in order to determine the reflections of the knowledge and skills acquired by the mother during the program on the child's literacy education were carried out in an individual education classroom in a special education institution. During the observation period, no intervention was made in the literacy activities of the mother and child together, and no time limit was made. During the observation, the mother and child sit opposite each other at the table. The researcher and the second observer recorded the mother-child behaviors through the observation form. In addition, during the process, the situations encountered in the process were recorded by the researcher with the researcher's diary.

\section{Validity and Reliability Studies}

For a scientific research, validity is the accuracy of the results; Reliability refers to the reproducibility of research results (Yıldırım \& Şimşek, 2013). In qualitative research that examines the existence and meaning of an event or phenomenon, there are some measures to be taken regarding validity and reliability. Many different methods are used to ensure validity and reliability in qualitative research (Patton, 2014). In this study, in order to increase the internal validity; Detailed description and purposive sampling methods were used to provide expert review, data diversity, long-term interaction, depth-oriented data collection and external validity. In order to ensure the reliability of the research, inter-observer reliability calculation, presentation of the findings without interpretation and protection of raw research data were carried out. Interobserver reliability level in the study was calculated using the formula: consensus / (consensus + disagreement) x 100 (Kırcaali-iftar \& Tekin, 1997; Miles \& Huberman, 1994). In this study, the interobserver reliability level was calculated as $91 /(91+13) \times 100=87.5$.

\section{Data analysis procedures}

Descriptive analysis was used in the analysis of the qualitative data obtained in this study. Descriptive analysis is frequently used in qualitative studies. According to Wolcott (1994, cited in Yıldırım \& Şimşek, 2013), descriptive analysis; The aim is to present the data in descriptive expressions by adhering to the data obtained and by quoting the participants' own statements from time to time. In descriptive analysis, the data should be presented to the reader in an organized and interpreted way (Patton, 2014; Yıldırım \& Şimşek, 2013). In addition, a clear and systematic approach should be adopted in the reporting process (Glesne, 2012; Yıldırım \& Şimşek, 2013).

Descriptive analysis is carried out in four stages. The researcher first creates an analysis framework in order to prevent data loss and erroneous interpretation of data (Yıldırım \& Şimşek, 2013). In the second step, the data is processed in the thematic framework in which the data is organized, and direct quotations are selected, in the third step, it defines the findings in an easy and understandable language by including direct quotations, and finally interprets the findings by explaining, relating, and interpreting the findings (Yıldırım \& Şimşek, 2013).

The data obtained in this study were first deciphered on the Microsoft Office Word program and then loaded into the MAXQDA qualitative data analysis program. Similar expressions of the 
participants were gathered under groups and examined, and direct quotations were included by selecting sample participant expressions. The processed data are presented with tables, graphics, and maps by using the matrix browser feature in the MAXQDA program.

\section{FINDINGS}

\section{1- Mother Education Program Draft}

Draft mother education program to ensure mother's participation in the literacy education process of children with special learning disability; It has been prepared on the basis of the "Basic Objectives of Turkish National Education" in Article 2 of the National Education Law No. 1739, the General Principles of Turkish National Education and the "General Principles of Special Education" in Article 4 of the Decree Law No. 573 on Special Education. The general aim of this program is to ensure the participation of the mother in the first literacy activities of the child with special learning disability. In the program, it is aimed to provide the mother with the knowledge and skills that her child needs in order to participate in the literacy education process. For this purpose, for the mother; It is aimed to gain various knowledge, skills and positive attitudes in the fields of special learning disabilities, teaching principles, literacy, preparation for reading and writing, and literacy with sound-based sentence method. At the end of the program, the mother participating in the program is expected to have the qualifications to provide guidance and assistance in the subjects taught by the teacher within the scope of literacy studies.

In terms of program family education program types; It was prepared based on the group according to the number of people, based on the institution according to the application environment, and on raising parents as teachers according to their goals. The program consists of two parts. In the first part, the program's objective, content, learning-teaching process, evaluation elements and specification table; In the second part, there are lesson plans prepared based on the program.

The objectives were determined by examining the relevant literature and the findings obtained from the pre-application. In the draft of the mother education program; There are specific learning disability, teaching principles, literacy, preparation for reading and writing, and learning objectives related to literacy teaching. The Turkish Language Curriculum (MEB, 2018) and the Special Learning Disability Support Education Program $(M E B, 2008)$ are the sources of the program's objectives in literacy studies. The opinions of six experts, including two specialists in the field of Turkish education, two field of curriculum and teaching, and two specialists in the field of special education, were consulted on the possible objectives created by examining the relevant literature. In line with the feedback received from the experts, the objectives of the program were rearranged and given its final form. The program includes objectives in the cognitive and affective domains.

A modular programming approach has been adopted while creating the content element of the program. While each learning unit in the education program creates a unity within itself, it shows independent features from other learning units. While editing the content; vitality, selfsufficiency, meaningfulness, validity, relevance, usefulness, learnability principles were taken into consideration. The content elements are arranged from concrete to abstract, from simple to complex, from easy to difficult, from known to unknown, and from the near to the far environment. The content of the program; It consists of five learning units: special learning disability, teaching principles, literacy, preparation for reading and writing, and teaching reading and writing with sound-based sentence method. 
Table 4. Elements of Mother Education Program Draft

\begin{tabular}{|c|c|c|c|c|c|}
\hline \multicolumn{4}{|c|}{$\begin{array}{l}\text { Objectives/ Sub-acquisitions } \\
\text { Objective 1: Knowledge of basic concents related to special learning disability }\end{array}$} & LTP & E \\
\hline \multicolumn{4}{|c|}{$\begin{array}{l}\text { 1.1. Makes the definition of special learning disability. } \\
\text { 1.2. List the characteristics of children with special learning disability. } \\
\text { 1.3. It refers to the learning disability of a child with a special learning disability. } \\
\text { 1.4. Express the general teaching principles for children with special learning disability. } \\
\text { Objective 2: Understanding the educational needs of the child with special learning disability } \\
\text { Sub-acquisitions: } \\
\text { 2.1. He/she exemplifies the characteristics of the child with special learning disability by associa } \\
\text { his/her own child. } \\
\text { 2.2. Summarizes general teaching principles for children with special learning disability. } \\
\text { Objective } 3 \text { : Internalizing the specific learning disability } \\
\text { Sub-acquisitions: } \\
\text { 3.1. Be willing to learn new information about specific learning disability. } \\
\text { 3.2. Curious about the characteristics of children with special learning disability. } \\
\text { 3.3. Becomes aware of the disability experienced by the child with special learning disability. } \\
\text { Objective 4: Supporting children with special learning disability } \\
\text { Sub-acquisitions: } \\
\text { 4.1. He/she is open to participate in the education of his child with special learning disability. } \\
\text { 4.2. It gives importance to emotional support to the child who has special learning disability. }\end{array}$} & 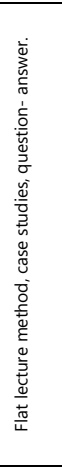 & 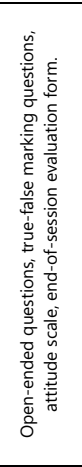 \\
\hline \multicolumn{3}{|l|}{ Objectives/ Sub-acquisitions } & & LTP & $\bar{E}$ \\
\hline \multicolumn{4}{|l|}{$\begin{array}{l}\text { Objective 5: Knowledge of teaching principles } \\
\text { Sub-acquisitions: } \\
\text { 5.1. Tells the definition of learning. } \\
\text { 5.2. Tells the definition of teaching. } \\
\text { 5.3. List the teaching principles. } \\
\text { Objective 6: Understanding the teaching principles } \\
\text { Sub-acquisitions: } \\
\text { 6.1. Explains learning with examples. } \\
\text { 6.2. Explains the teaching principles. }\end{array}$} & 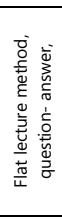 & 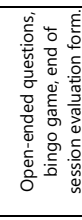 \\
\hline \multicolumn{2}{|l|}{$\begin{array}{l}\text { Objectives/ Sub-acquisitions } \\
\text { Objective 7: Knowledge of basic concepts about lite }\end{array}$} & Content & & LTP & $\mathbf{E}$ \\
\hline \multicolumn{4}{|l|}{$\begin{array}{l}\text { Objective 7: Knowledge of basic concepts about literacy } \\
\text { Sub-acquisitions: } \\
\text { 7.1. Makes the definition of reading and writing. } \\
\text { 7.2. Expresses the purpose of reading and writing. } \\
\text { 7.3. Lists different types of texts (novel, memoir, bibliography, an } \\
\text { mania, etc.). } \\
\text { Objective 8: Comprehending the state of being literate } \\
\text { Sub-acquisitions: } \\
\text { 8.1. He exemplifies the importance of literacy by relating it to his } \\
\text { 8.2. Explain the importance of literacy for the education of the ch } \\
\text { 8.3. It expresses the problems that illiteracy can cause. } \\
\text { 8.4. Gives examples of different text types. } \\
\text { Objective } 9 \text { : Internalizing the importance of literacy } \\
\text { Sub-acquisitions: } \\
\text { 9.1. It gives importance to literacy education. } \\
\text { 9.2. Express their feelings about literacy. } \\
\text { 9.3. Interested in reading and writing materials. }\end{array}$} & 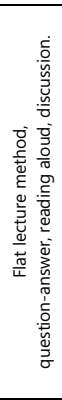 & 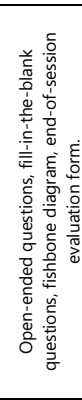 \\
\hline \multirow[b]{2}{*}{$\begin{array}{l}\text { Objective 10: Knowledge of literacy preparatory studies } \\
\text { Sub-acquisitions: } \\
\text { 10.1. tells the purpose of literacy preparation studies. } \\
\text { 10.2. List the preparatory work for reading. } \\
\text { 10.3. List the preparatory work for writing. } \\
\text { Objective } 11 \text { : Comprehending the literacy preparation st } \\
\text { Sub-acquisitions: } \\
\text { 11.1. Gives examples of preparatory studies for reading. } \\
\text { 11.2. Gives examples of preparatory work for writing. } \\
\text { Objective 12: Implementing literacy preparatory studies } \\
\text { Sub-acquisitions: } \\
\text { 12.1. Prepares activities related to literacy preparation stu } \\
\text { 12.2. He/she applies the activity he/she prepared about l } \\
\text { preparation studies. }\end{array}$} & \multicolumn{3}{|l|}{ Content } & LTP & $\mathbf{E}$ \\
\hline & \multicolumn{3}{|c|}{$\begin{array}{l}\text { 4. PREPARING TO READ AND WRITE } \\
\text { 4.1. Purpose of Literacy Preparation Studies } \\
\text { 4.2. Preparation for Reading } \\
\text { 4.2.1. Sitting } \\
\text { 4.2.2. Voice Games } \\
\text { 4.2.3. Book Holding and Page Turning } \\
\text { 4.2.4. Visual reading } \\
\text { 4.2.5. Encouragement to read } \\
\text { 4.2.6. Reading Left to Right } \\
\text { 4.2.7. Rest the Eyes } \\
\text { 4.2.8. Breath-Breathing } \\
\text { 4.3. Preparation for Writing } \\
\text { 4.3.1. Hand gestures } \\
\text { 4.3.2. Painting } \\
\text { 4.3.3. Holding a pen } \\
\text { 4.3.4. Writing from Left to Right } \\
\text { 4.3.5. Line Studies } \\
\text { 4.4. Suggestions for Families in the Literacy Preparation Process }\end{array}$} & 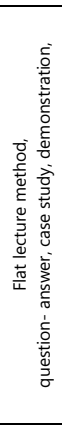 & 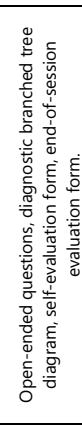 \\
\hline Objectives/ Sub-acquisitions & & & Content & LTP & E \\
\hline $\begin{array}{l}\text { Objective 13: Basic concepts of sound-based sentence method } \\
\text { Sub-acquisitions: } \\
\text { 13.1. He says that the sound-based sentence method is a kind of } \\
\text { 13.2. Lists the steps of the sound-based sentence method. } \\
\text { 13.3. Sorts the letter groups in accordance with the sound-based } \\
\text { Objective 14: Comprehending the sound-based sentence metho } \\
\text { Sub-acquisitions: } \\
\text { 14.1. Compares the sound-based sentence method with the met } \\
\text { (sentence decoding etc.). } \\
\text { 14.2. Explain the application stages of the sound-based sentence } \\
\text { Objective 15: Applying the sound-based sentence method } \\
\text { Sub-acquisitions: } \\
\text { 15.1. It does the work of feeling the sound. } \\
\text { 15.2. It does voice recognition work. } \\
\text { 15.3. Makes voice reading and writing exercises. } \\
\text { 15.4. Makes work on forming syllables from sounds. } \\
\text { 15.5. Makes syllable reading and writing exercises. } \\
\text { 15.6. Makes word reading and writing exercises. } \\
\text { 15.7. Makes sentence reading and writing practice. } \\
\text { 15.8. Makes text reading and writing exercises. }\end{array}$ & ich he/she learn & and write & $\begin{array}{l}\text { 5. READ AND WRITE TEACHING } \\
\text { WITH SOUND-BASED SENTENCE } \\
\text { METHOD } \\
\text { 5.1. Sound Based Sentence Method } \\
\text { 5.2. Stages of Sound Based Sentence } \\
\text { Method } \\
\text { 5.2.1. Sensing and Recognizing Voice } \\
\text { 5.2.2. Reading and Writing Audio } \\
\text { 5.2.3. Creating Syllables, Words, } \\
\text { Sentences } \\
\text { 5.2.4. Creating text } \\
\text { 5.3. Letter Groups } \\
\text { 5.4. Reading-Writing Practices with } \\
\text { Sound-Based Sentence Method } \\
\text { 5.5. Advice to Families }\end{array}$ & 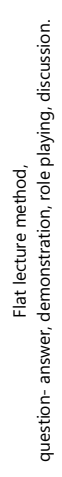 & 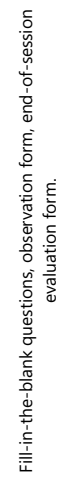 \\
\hline
\end{tabular}

LTP: Learning-teaching process 
In the learning-teaching process, the dominant teaching approach in the program is the teaching strategy by presentation. Accordingly, the content is presented by the teacher in a hierarchical way from general to specific. In the introduction part of the lesson plans; There are activities aimed at attracting attention, motivating and informing the target. In the development part of the course, active participation, establishing relationships, making applications, giving feedback and corrections were put to work. In the conclusion part of the lesson plans, there are various evaluation activities. Methods such as narration, question-answer, discussion, role playing, and case study were used in the learning-teaching process of the mother education program draft. In this way, by using different teaching methods, it is aimed to ensure the active participation of mothers who assume the role of learner in the process as much as possible, and to learn by doing experience.

Process evaluation and total evaluation activities are included in the program. An interactive approach has been adopted in the implementation process of the program, and evaluations are made in the form of question-answer and discussion. In line with the answers received from the participants, immediate feedback and corrections are given. At the end of each lesson in the program, open-ended questions, filling in the blanks, true-false marking, etc. evaluation activities. In addition, one of the alternative evaluation techniques; fishbone, diagnostic branched tree, selfassessment, observation forms and attitude scales are used. After the completion of the implementation process of the program, a total evaluation is made through the observation form.

\section{2- Findings Obtained from the End of Session Evaluation Forms}

The mother training program was implemented with mothers who were the participants of the study in five sessions and fourteen lesson hours. The positive views of the participant mothers about the learning and teaching process; the use of instructional technology, doing activities, practicing, presenting the content with examples, the way of evaluation and the attitude of the educator (Figure 2).

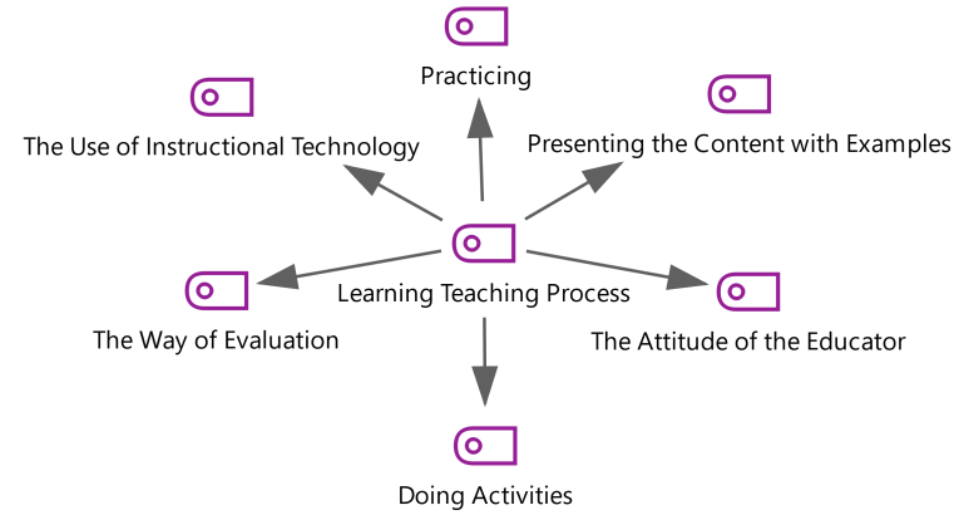

Figure 2. Views of Mothers on the Learning-Teaching Process

Participating mothers stated that the use of instructional technologies in the learningteaching process helped them understand the content better. Another situation that mothers find positive regarding the learning-teaching process is activities and practices during teaching. They stated that learning in this way becomes more enjoyable.

What I liked the most in today's lesson; Our teacher made us watch videos on the computer and we saw what the teacher told us. $\left(M_{2}\right)$

In today's lesson; My friend and I had each other read and write. Our teacher also checked on us, I learned by doing. $\left(M_{1}\right)$ 
Another situation that mothers are pleased with is the presentation of the content with examples and the positive attitude of the educator. Mothers also expressed a positive opinion about the evaluation activities carried out at the end of the teaching sessions.

In today's lesson; I learned in the best way by participating in the class and giving examples in return for our teacher's examples. $\left(M_{2}\right)$

What I like in today's lesson; We had a picture exam. As in the children's book, it happened. $\left(M_{3}\right)$

Regarding the learning and teaching process of mothers; They stated that they felt negative emotions due to their negative approach to their children and noticing the mistakes they made in their children's education before, and that they had disability because they had not participated in a teaching activity for a long time.

What I dislike the most in today's lesson; I was overreacting to my child. I realized that I made a mistake and regretted it. $\left(M_{1}\right)$

What I don't like the most in today's lesson; I learned what I knew was right. I realized that I made a mistake. $\left(M_{3}\right)$

In today's lesson, the most I had a hard time avoiding a class for a long time. $\left(M_{4}\right)$

\section{3- Findings Obtained from Post-Implementation Interviews}

In this study, after the mother education program draft was implemented, the opinions of the participating mothers and teachers about the mother education program draft were taken during the literacy education process. Under this heading, findings related to postimplementation interviews with mothers and teachers are presented.

In the interview, which was held to determine the views of the mothers about the program, questions were asked about the positive/negative consequences of the program, their level of satisfaction with the program, and their views on the implementation process of the program. The positive consequences of the program based on the findings obtained from the mother's views; productive homework/repetition, acquiring new knowledge and skills, recognizing the mistakes made in the child's education, taking a role and responsibility in the child's education, positive mother-child communication and making friends (Table 5).

Table 5. Positive Consequences of the Mother Education Program Draft

\begin{tabular}{lll}
\hline Positive Consequences of the Program & n & Participant \\
\hline Doing Homework/Repetition & 4 & $M_{1}, M_{2}, M_{3}, M_{4}$ \\
Acquiring New Knowledge and Skills & 4 & $M_{1}, M_{2}, M_{3}, M_{4}$ \\
Recognizing Your Mistakes & 4 & $M_{1}, M_{2}, M_{3}, M_{4}$ \\
Taking Role and Responsibility in Child's Education & 3 & $M_{1}, M_{3}, M_{4}$ \\
Positive Mother-Child Communication & 4 & $M_{1}, M_{2}, M_{3}, M_{4}$ \\
Make friends & 3 & $M_{1}, M_{2}, M_{4}$ \\
\hline
\end{tabular}

When Table 5 is examined, the positive consequences of the program for mothers are seen. However, considering the achievements of the draft mother education program, it can be said that there are some unforeseen positive consequences for the program. The predicted positive consequences of the draft mother education program are taking role and responsibility in the education of the child, acquiring new knowledge and skills, positive mother-child communication and doing homework/repetition (Figure 3). 


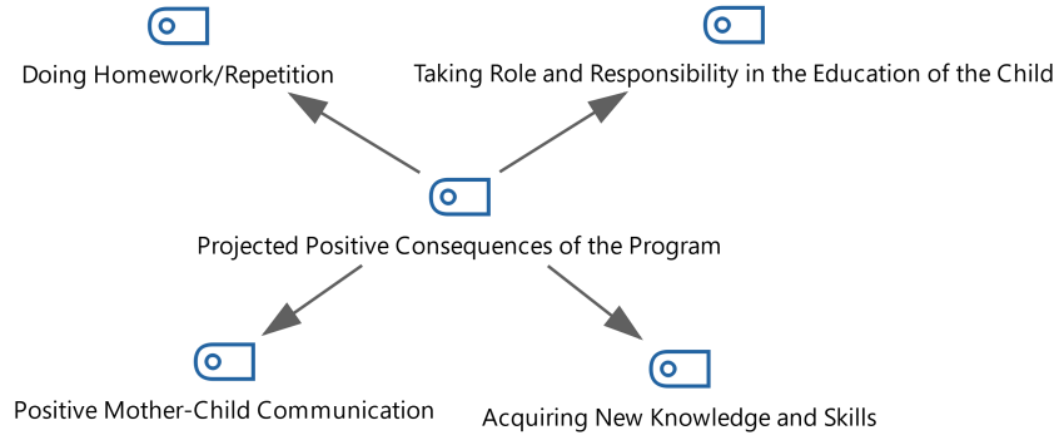

Figure 3. Projected Positive Consequences of the Draft Mother Education Program

Participating mothers stated that they are willing to take more roles and responsibilities regarding their children's education. $\mathrm{M}_{3}$ stated that her fourth-grade child would take a more active role in the secondary school education process and plan to cooperate with the child's teacher, while another mother stated that she aimed to do studies that would contribute to the literacy process in her child's free time.

For example, in middle school, I can talk to a teacher one-on-one. I can take individual training.

I can get an individual education from him, so I know my rights. I learned them too. Like, I didn't

know before. If you hadn't told me, I wouldn't have known. ( $\left.\mathrm{M}_{3}\right)$

I will try to write small poems from now on. I will increase the reading time a little more. That's

for sure. It will be over an hour. In short, I will devote everything to my child. $\left(M_{4}\right)$

In addition, mothers through the program; mentioned that they have acquired new knowledge and skills related to special learning disabilities, literacy education process and teaching principles. They state that the knowledge and skills they acquire, especially about the characteristics of children with special learning disability, are important for them, and thus they can communicate more positively with their children. A mother, on the other hand, emphasizes the changes in her approach to her child as a result of the information she gained about the individual differences of her child with special learning disability.

I felt $C_{3}$ like a normal child. But now, thanks to our teacher, I felt that my child was a special child. For example, there is no problem in his intelligence, there is no problem in his hands or feet, but I felt that he could not do it like other children. I was very angry with my child because he couldn't do it before. "Your other friends are doing it, why can't you?" I was saying. Turns out it wasn't in the kid's own hands. What he couldn't do was not in his own hands. My child is different. He's a special kid. $\left(M_{3}\right)$

Participating mothers expressed the opinion that they could use the knowledge and skills they acquired in the program in their literacy work with their children. Participating mothers emphasized that they gave feedback on the reading mistakes made by the children during the literacy activities, and they repeated it more frequently.

I am able to speak more respectfully to my child. I can understand it. I feel that he is not in his control, so I know. I used to get very angry while trying to read and write, my son, why can't you do it? Now, I sit it on my lap. I read the same word three times or four times, and he reads it together. For example, I was angry before. I was reading it once, the second I was expecting him to read it. $\left(M_{3}\right)$

Participating mothers stated that they take into account the teaching principles in their domestic work with their children, and thus they do homework and repetition more efficiently with their children.

For example, learning, teaching, telling. Then things that we can do while having fun. I learned them. I really thank you very much. I really wanted to participate in something like this. When 
we teach our child something, we learned how to do it. By telling, not by getting angry, but by doing everything with love. $\left(M_{2}\right)$

In line with the interviews with the participating mothers, it was seen that the program caused some unforeseen consequences in terms of making friends/peer interaction and noticing the mistakes made in the child's education. Unforeseen positive consequences are presented in Figure 4.

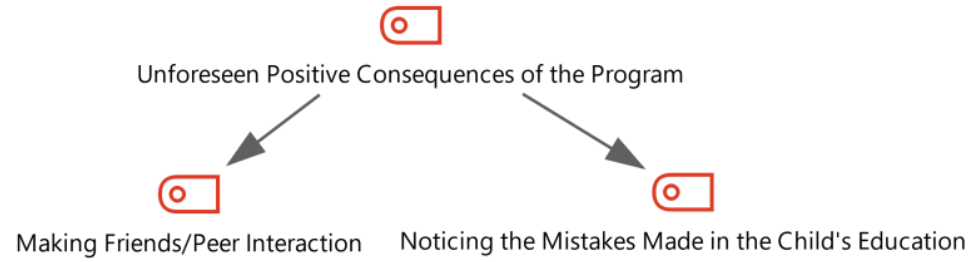

Figure 4. Unforeseen Positive Consequences of the Draft Mother Education Program

Participating mothers met with mothers who have children with similar characteristics and made new friendships during the implementation of the mother training program draft. It can be thought that this situation contributes to emotional support for mothers. In addition, mothers in the role of students stated that they benefited from each other's positive/negative experiences by engaging in peer interaction.

I knew I wasn't the only one (in this case). I met other mothers. What they know is wrong in my opinion. I learned it. Our teacher and our teacher also contributed to this. So, it was good, we had people to share our troubles with. We are not alone; I know that well. I learned. I enabled other children's mothers to benefit from my own knowledge. I benefited from their knowledge. It was positive, so I'm glad. It was good for us, and it was good for the education of our children. I mean, if there is such a program again, I would like to participate again. $\left(M_{4}\right)$

In the draft of the mother education program, there are no gains related to the wrong or inadequate behaviors of mothers in their children's education. From this perspective, it can be seen as an unforeseen positive outcome that mothers realize the mistakes they make in their children's education. Mothers describe this situation based on their own experiences as follows:

I think he learns how to treat the child, learns what the child's right is. If the child says no, we learn not to go against it. We learn that the child is also an individual. So, it shouldn't always be what your parents say. We should listen to our child. It's aimed at them. For example, before, (my child) was like my slave. If I say get up, he gets up; if I say sit, he sits. But now it gets better when you give the child a say. $\left(M_{3}\right)$

Depending on the mothers' statements, it was observed that the draft mother education program had some negative consequences. These negative consequences are in the form of the child's feeling of inadequacy in terms of learning disability and the mother's individual feeling of inadequacy and generally focus on the emotional state of the mothers (Table 6).

Table 6. Unforeseen Negative Consequences of the Mother Education Program Draft

\begin{tabular}{lll}
\hline Negative Consequences of the Program & n & Participant \\
\hline Feeling Incompetent About Your Child's Learning Disability & 2 & $\mathrm{M}_{2}, \mathrm{M}_{3}$ \\
Mother's Feeling of Inadequacy & 1 & $\mathrm{M}_{1}$ \\
\hline
\end{tabular}

In the draft of the mother education program, there are no gains in dealing with the behavioral problems of the child with special learning disability and in dealing with the disability encountered in the education of the child. These negative feelings that the program makes for mothers are the unforeseen negative consequences of the program. Participating mothers stated that they had disability in coping with the behavioral problems of their children with special learning disability and that they felt inadequate in this regard. One mother, on the other hand, 
mentioned that she felt some anxiety because of her insufficient prior knowledge and her husband's lack of support in her child's education.

I learned what my child can and cannot do because of his attention deficit. On the negative side, for example, I don't know how to deal with my child. So, I find it difficult, I think about them a lot. For example, I used to say that if he learns to read and write, it will pass (special learning disability). But it wasn't all about reading and writing. I felt like I was just getting started. I felt like I was at the beginning of the road. I do not know. God give convenience. $\left(M_{3}\right)$

Negative situation, I am a primary school graduate, teacher. My family didn't. I would too, but it didn't work. When I got married, I enrolled in open education. I have three children. I don't know how to get enough of these kids. You showed, for example, fairy tales, stories, legends. I didn't know these. So, I would call it all stories. I saw that I was missing. More these (children) will go to middle school, high school. If you say my husband, he will never touch the children. I felt alone. $\left(M_{1}\right)$

During the interviews with the mothers of children with special learning disability, questions were asked about the implementation process of the program. During the implementation of the program, mothers; it is seen that they are satisfied with the use of role-playing method, the use of instructional technology and the presentation of the content with examples (Table 7).

Table 7. Views of Mothers on the Implementation Process of the Program

\begin{tabular}{lll}
\hline Opinions on the Implementation Process of the Program & $\mathbf{n}$ & Participant \\
\hline Using the Role-Playing Method & 2 & $M_{1}, M_{3}$ \\
Using Instructional Technology & 2 & $M_{1}, M_{2}$ \\
Presenting Content with Examples & 1 & $M_{4}$ \\
\hline
\end{tabular}

Participating mothers state that the use of role-playing method during teaching contributes to their better learning, and the use of presentations during teaching is also a positive situation.

For example, the teacher (researcher) had an application made, I learned in those applications, how can I treat my child better. For example, I can teach my child how to apply the output of letters or something by emphasizing them. It would be better. $\left(M_{3}\right)$

For example, a friend of mine is a student, and I am a mother. Here you are trying to read it. I like it so much. We had fun, we laughed. And you told us to do it like that, it would be better if you did it like that. So, I enjoyed it very much. We also watched videos. We talked. I like these.

$\left(M_{1}\right)$

In the study, in order to determine the opinions of the teachers about the mother education program draft; Questions were asked to determine the satisfaction with the program, the changes in the literacy level of the student, the mother's participation in education and the support received from the mother. Teachers' positive opinions about the program focus on mother and child motivation, homework/repetition, cooperation, while negative opinions are on illiterate mothers and the continuity of program effects. The teachers' views on the program are presented in Figure 5.

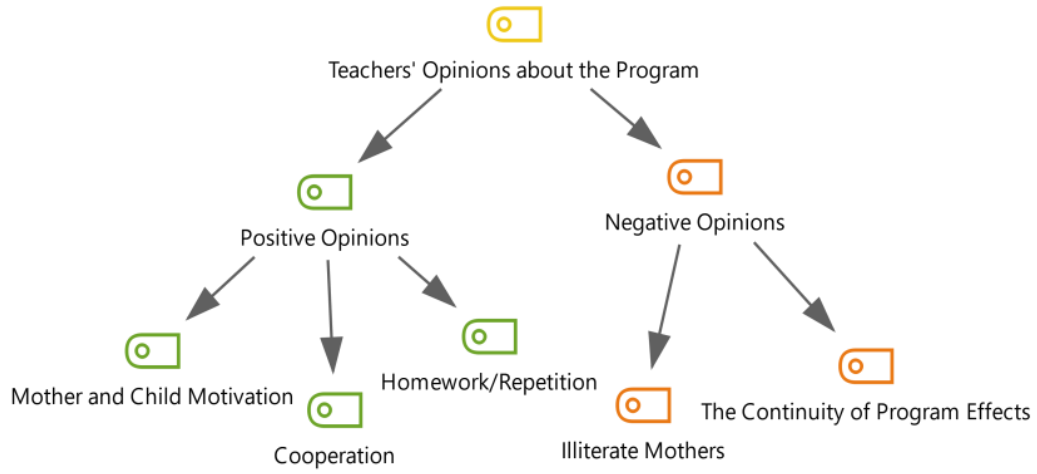

Figure 5. Positive and Negative Opinions of Teachers on the Draft Mother Education Program 
Teachers' positive opinions about the program; mother's motivation, child's motivation, homework/repetition, and cooperation (Table 8).

Table 8. Positive Opinions of Teachers on the Draft Mother Education Program

\begin{tabular}{lll}
\hline Positive Opinions & n & Participant \\
\hline Homework/ Do Not Repeat & 4 & $\mathrm{~T}_{1}, \mathrm{~T}_{2}, \mathrm{~T}_{3}, \mathrm{~T}_{4}$ \\
Cooperation & 3 & $\mathrm{~T}_{1}, \mathrm{~T}_{2}, \mathrm{~T}_{4}$ \\
Mother and Child Motivation & 3 & $\mathrm{~T}_{1}, \mathrm{~T}_{3}, \mathrm{~T}_{4}$ \\
\hline
\end{tabular}

All of the participating teachers stated that there were positive changes in the behavior of mothers doing homework and repetition with their children after the program. According to the teachers, another positive reflection of the program is the increase they observed in teacherparent cooperation.

Mom is already a very caring lady. They would complete their writing assignments but skipped a little reading assignment. This is obvious already. She gets her reading studies done better, she. This is the most obvious change I have observed. $\left(T_{2}\right)$

According to the teachers' opinions, another positive contribution of the draft mother education program is the increase in the motivation of the mother and the child. Teachers describe this change they observed as follows:

As I said, parents take care of their children. When a parent takes care of his child, the child's desire also increases. This time, the child says that my mother is taking care of him at home, I have a teacher at school. So, it all works for me. This time, the child's willingness is also increasing. The more parents make an effort for their children, the more the teachers make an effort. That's why I think the parent relationship is very important. $\left(T_{4}\right)$

The negative opinions of teachers about the draft mother education program are related to the continuity of the effects of the program and illiterate mothers and are presented in Table 9.

Table 9. Negative Opinions of Teachers Regarding the Mother Education Program Draft

\begin{tabular}{lll}
\hline Negative Opinions & $\mathbf{n}$ & Participant \\
\hline Continuity of Program Impacts & 2 & $\mathrm{~T}_{3}, \mathrm{~T}_{4}$ \\
Illiterate Mothers & 1 & $\mathrm{~T}_{2}$ \\
\hline
\end{tabular}

Although the teachers stated that the motivation of the mothers and their participation in education increased after the program, they expressed the opinion that this positive effect of the program may disappear after a while. Another criticism of the draft mother education program is that illiterate mothers cannot benefit from the program.

I wish it could have been longer. I wish we could coordinate in the longer term. Because in a short time yes, the parents were motivated. But maybe after a month they will be able to break off. $\left(T_{4}\right)$

There are mothers who need it more. Most of them are also illiterate. It is very difficult to support your child. More general things can be done for these mothers as well. $\left(T_{2}\right)$

In the last interviews with the teachers, questions were asked about the support that the teachers received from the mothers after the program. The support that teachers receive from mothers after the program is in the form of complete homework, free reading at home, communication and arranging the child's working environment (Table 10).

Table 10. Support from Mothers After the Program

\begin{tabular}{lll}
\hline Support from Mothers & n & Participant \\
\hline Complete Homework & 4 & $T_{1}, T_{2}, T_{3}, T_{4}$ \\
Free Reading at Home & 3 & $T_{1}, T_{3}, T_{4}$ \\
Providing Communication & 3 & $T_{1}, T_{3}, T_{4}$ \\
Organizing a Child's Work Environment & 1 & $T_{4}$ \\
\hline
\end{tabular}


When Table 10 is examined, it is seen that teachers receive support most frequently for completing homework and organizing the child's work environment least frequently after the program. According to the teachers' opinions, there was a positive change in mother-child free reading activities at home after the program.

My problem was that at home, the letters were pronounced not with their sound, but with the way they were pronounced in the alphabet. I told you too. You've worked on this for the mother. You taught. Thank you. It was helpful in this regard. Repetitions at home began to be done more smoothly. Here, we are making an effort so that students can learn and gain something. It is a good thing for me that the family supports us. $\left(T_{1}\right)$

The financial situation of the family is not very good. I gave a book here. For home reading. They are reading, they are making signs where they left off. It would be great if they continue like this. $\left(T_{3}\right)$

For example, our parent said that she created a special study area for her child. She said that they do their homework within a certain hour daily. I think it's good about it. $\left(T_{4}\right)$

In the light of the findings obtained from the post-implementation interviews with the teacher, the suggestions of the teachers for the mother education program are to include the parents of children with intellectual disabilities, as well as the parents of different disability groups, to provide guidance to the mothers after the program, and to involve the teachers in the process (Figure 6).

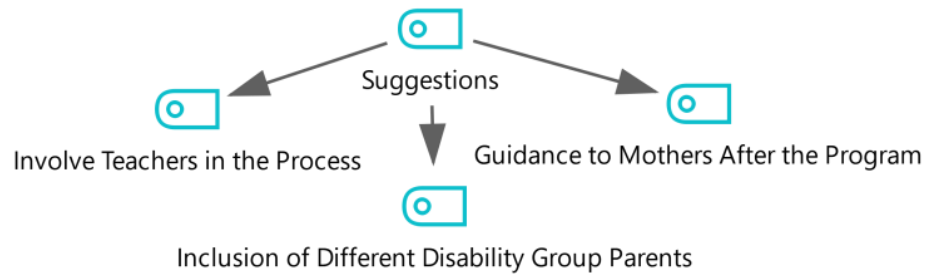

Figure 6. Teachers' Suggestions for the Mother Education Program Draft

A teacher suggested that teachers should be included in the implementation process of the program because of the continuity of the effects of the program and the teachers' need for information on this subject.

I wish we could include teachers. Good moms are enthusiastic right now. He's trying to do. If it continues, that's very good. But if they don't continue... If you had worked on the teachers here, for example, how will they guide mothers in the ongoing process, what should they do... It would be better. We usually have young friends here. It would be more beneficial for them. $\left(T_{3}\right)$

\section{4- Findings Obtained from Observation of Mother-Child Literacy Practices}

In the study, in order to examine the reflections of the mother education program draft on mother-child studies; mother-child studies were observed before and after the program was implemented. In the observation form, scores were made as yes $=3$, partially $=2$, no $=1$. Then, the total score was calculated for each observation form. The total score from the first observation and the total score from the last observation were converted into percentage values and interpreted with a graphic. The percentages of correct behavior observed during the practice of mothers with their children are presented in Graph 1. 


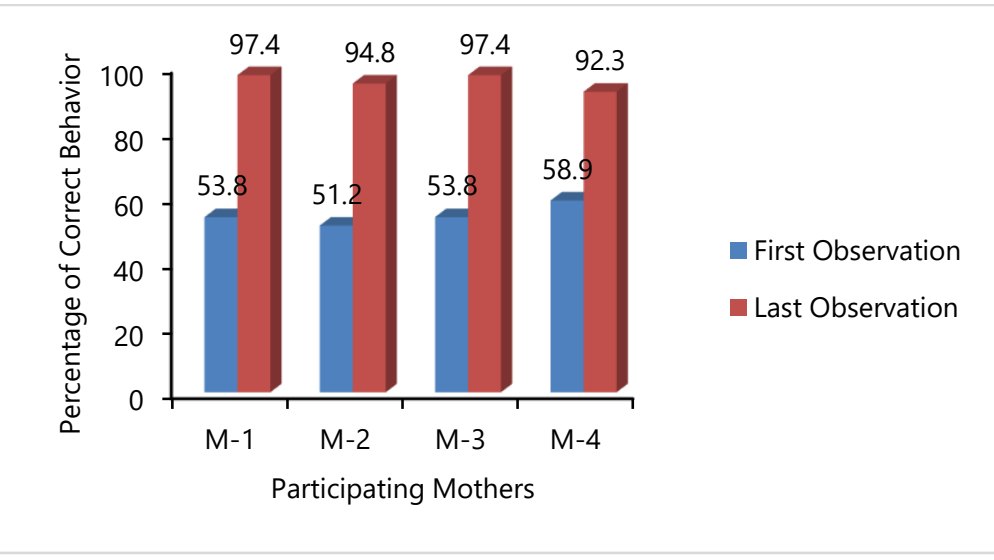

\section{Chart 1. Percentages of Correct Behavior Observed During Mother-Child Studies}

When Graph 1 is examined, it is seen that the correct behavior of mothers in their practices with their children has increased positively. In the first observations made with mothers and children, it was observed that mothers generally exhibited their ability to read letters, write letters, syllables, syllables, words, and sentences. It was observed that the mothers had the most difficulty in sensing sounds, recognizing sounds, forming syllables from sounds, writing words, writing sentences, making text read and text printing. The most common mistakes mothers make; it is the behavior of directly reading and printing the letter without doing voice recognition and feeling. Another negative situation is that he tries to make the child read syllables without having them do syllable formation (sound cracking) studies from sounds.

In the post-program observation with mothers and children, it was observed that mothers were generally able to guide the first literacy activities. However, it was observed that they had some disability in forming syllables from sounds and writing text. forming syllables from $M_{1}, M_{2}$, $M_{4}$ sounds; $M_{2}, M_{3}$ and $M_{4}$ were able to partially complete the text printing works.

\section{DISCUSSION, CONCLUSION AND RECOMMENDATIONS}

This study is a program development research. The process in program development studies; it continues as designing a system, implementing it, and evaluating the results (Ornstein \& Hunkins, 1998; Richey \& Klein, 2005; Varış, 1969). In this study, first, a mother education program was developed to ensure mother participation in the literacy education processes of children with special learning disability. Afterwards, the program was applied with the mothers of children with special learning disability and the results were evaluated. Due to the nature of curriculum development work, the draft of the mother education program is presented as a suggestion (Richey \& Klein, 2005).

After the implementation of the program, the opinions of the mothers on the program were determined through interviews. At the end of the application, it was seen that the program had some positive and negative consequences. According to the mother's opinions, the positive outcomes of the program are productive homework and repetition, acquiring new knowledge and skills, taking role and responsibility in the child's education, and positive mother-child communication. Mothers stated that after the program was implemented, they took more roles and responsibilities for their children's education and did homework and repetitions with their children more efficiently. In addition, they stated that their children acquired new knowledge and skills in terms of disability, literacy studies and teaching principles, and that they communicated better with their children as a result of using these knowledge and skills. In the literature, there are studies supporting that the participation of the family in literacy education has positive contributions to the child's literacy studies and family-child communication. For example, Kılıç 
(2018) developed a family literacy program for primary school 1st grade parents in his research. According to the parents' opinions, after the program, the parents stated that they learned to support their children, their children's literacy improved, and they communicated more positively with their children. Ölmez (2017), in her research with first-year students' parents, developed an education program to ensure that parents participate in literacy education of their children. Findings obtained from teacher and parent interviews after the implementation of the program; It is stated that the program contributes to the more active participation of parents in the literacy process, their awareness about literacy education increases, they do homework more easily with their children and strengthens their communication with the teacher.

In the draft of the mother education program developed within the scope of the study, there are subjects related to special learning disabilities and teaching methods as well as literacy studies. The mothers who participated in the study stated that they benefited from the program in terms of their children's disability characteristics and how to teach their children better. Similarly, Bayraklı (2016); In the study, it was concluded that the mother education program on inclusion in preschool improved the skills of mothers to recognize their children's disability, support and teach their children, and strengthen mother-teacher cooperation.

The mothers who participated in the study stated that they took more roles and responsibilities for the education of their children. One mother even mentioned that she plans to meet with her teachers individually during her child's secondary school education and request to benefit from appropriate special education services for her child. It is a necessity to organize meetings and interviews in order to make the transition between education levels of individuals with special needs more successful (Bakkaloğlu, 2013; Bayraklı, 2016). In the education of the individual with special needs, all concerned should cooperate and assume the roles and responsibilities of the child in solving the disability (Sorani-Villanueva, McMahon, Crouch, \& Keys, 2014).

According to the opinions of the mothers participating in the study, another outcome of the program is that mothers make friends. When the researches were examined, it was seen that parents with special needs children needed social support at a very high level (Sahay, Prakash, Khaique, \& Kumar, 2013; Özsoy, Özkahraman, \& Çallı, 2006; Tekinarslan, Sivrikaya, Keskin, Özlü, \& Rasmussen, 2018). In the draft of the mother education program proposed within the scope of the study; There are no gains regarding the social needs of the mother. However, during the program implemented as group training, mothers met with parents who had children with similar characteristics and exchanged views. This situation is thought to provide social support to mothers and is an unforeseen positive outcome for the program.

The findings of the interviews made with the teachers after the program was implemented show that the program increased the motivation of the mother and the child. It is seen that there are similar research findings in the literature. In his research, Ölmez (2017) emphasized that the participation of the family in the child's literacy education after the parent information program contributed positively to the motivation of the children. It is known that there is a positive relationship between the motivation of the child and learning to read and write (Başal \& Batu, 2002). In this case, it can be thought that the increase in the motivation of the mother and the child plays a positive role in the education of the child in a cyclical manner.

Another finding obtained from the teachers is that after the program, there was an increase in the mothers' behaviors to repeat and do homework with their children. It is seen that there are some studies in the literature to increase the study skills of children with special learning disability. Hunt, Soto, Maier, and Doering (2003) developed a training program to improve the study skills of children with special needs. According to the results obtained from the study, this interactive approach; These studies had positive effects on academic skills, peer interaction, and participation in classroom activities. 
The mothers participating in the study had not participated in family education before; it was seen that they only gained knowledge through general seminars and meetings given at school. In addition, all the participating teachers supported the view that families should participate in education and that families should receive education but stated that they did not organize family education before. The help provided by the teachers to the families is limited to informing in and out of lessons and via telephone. Similarly, Şanlı (2012) concluded in his research that participation in family education is at a low level and one of the reasons for this may be insufficient education for families in private education institutions.

In the study, Although there are findings that the mother education program draft makes positive contributions to the mother's child's literacy education, no study has been conducted on the needs of teachers regarding the literacy education process. The fact that teachers are not included in the program can be seen as a limitation in terms of the study. As a matter of fact, in the last interviews with the teachers, a finding was reached those especially younger teachers should be supported in this regard. In this case, it can be thought that studies should be carried out to ensure the participation of the family in the literacy education process with the teachers. When the literature is examined, it is seen that it is emphasized that teachers are supported in working with the family. (Lindberg, 2014; Akalın, Demir, Sucuoğlu, Bakkaloğlu, \& Isşcen, 2014).

Another criticism of the teachers towards the draft mother education program proposed in this study is that illiterate mothers cannot participate in the program. In this study, which is based on the argument that the mother provides help and support for her child in literacy studies, the prerequisite feature determined for mothers is that mothers are literate. However, when the literature is examined, it is seen that there are also studies on parents of illiterate children (Darling \& Hayes; 1989, Rodriguez- Brown, 2004). Such programs primarily serve to contribute to the child's literacy work in the process that continues to improve the literacy skills of the parents. For example, Family Literacy: Learning Development, Education Project; It includes a series of regulations aimed at ensuring the learning of their children and increasing the cooperation between the family and the school by improving the literacy skills of families (Rodriguez- Brown, 2004). The project initially emerged with the aim of improving the literacy skills of illiterate Spanish immigrants and later became widespread. Another study on this subject is the Kenan Family Literacy Project (Darling \& Hayes, 1989). In this project, children aged 3 or 4 and their parents receive training. While families are trained in terms of various academic skills, their children receive comprehensive preschool education. It was concluded that the education program implemented within the scope of the project increased the academic performance and social skills of parents and children. In this context, another limitation of the study is the exclusion of illiterate mothers from the study.

Within the scope of this study, mother-child literacy studies were also observed before and after the implementation of the mother education program draft. In the observations made, it was found that there was an increase in the percentage of correct behavior of the mother in motherchild studies after the program was implemented. This situation was interpreted as the mother's ability to reflect the knowledge and skills she gained from the program to the literacy studies she did with her child, and the program had positive reflections on the child's literacy studies. In the literature, there are studies emphasizing that the participation of families in the literacy process has positive contributions to the child. For example, Özen- Altınkaynak (2014) developed a familybased literacy preparation program in his research. According to the results obtained from the research carried out in the experimental design; It was observed that there was a significant difference in the early literacy skills of the children whose mothers participated in the literacy preparation program. According to the findings of Baker (2013), in which he examined the effects of parents' participation in home literacy on preschool children, it was observed that the children of parents who participated in home literacy experiences developed more cognitively, emotionally, and socially. Senechal and Young (2008) determined the effects of the participation 
of the family in the literacy process from the pre-school period to the third grade of primary school through a meta-analysis of 16 interventional studies. According to the findings obtained from the research, the participation of the family in the literacy process contributes positively to the literacy skills of both children with special learning disability and normal children.

As a result; According to the statements of the participants, the draft of the mother education program; It is thought that mothers have positive contributions in terms of establishing cooperation with the teacher, having their children do homework and repetitions for literacy education at home, and communicating better with their child and with the teacher. Teachers stated that there were positive changes in the motivation of mothers and children, and that mothers participated more actively in the literacy education of their children. In addition, based on the observation findings, it is thought that the draft mother education program has positive reflections on mother-child literacy studies. In this context, suggestions for future research are presented below:

- In this study, a draft mother education program for literate mothers was proposed. According to the findings obtained from the participating teachers, it is seen that illiterate mothers also need such trainings. For these mothers, A mother education program can be developed to ensure that the mother learns to read and write first and then the child participates in literacy education, and studies can be conducted on the effectiveness of the program.

- In the study, a draft education program was proposed to increase maternal participation in the literacy education process of children with special learning disability. According to the findings obtained from the opinions of the teachers within the scope of the study, it is thought that the parents of children with different disabilities, especially the parents of children with intellectual disabilities, also need similar training. Based on this finding, training programs can be developed for parents of children with different disability types.

- In this study, it was found that the draft of the mother education program had positive reflections on the mother's participation in the literacy education process. Based on this finding, different parent education programs can be developed to ensure participation in the education of children with special learning disability and their effects can be investigated.

\section{REFERENCES}

Akalın, S., Demir, Ş., Sucuoğlu, B., Bakkaloğlu, H. \& İşcen, F. (2014). The needs of inclusive preschool teachers about inclusive practices. Eurasian Journal of Educational Research, 54, 39-60. DOI:10.14689/ejer.2014.54.3

Akçin, N. (2009). Öğrenme güçlüğü gösteren çocukların yazma sürecinde gösterdiği özellikler. Marmara Üniversitesi Atatürk Eğitim Fakültesi Eğitim Bilimleri Dergisi, 29, 5-18. Retrieved from https://dergipark.org.tr/tr/pub/maruaebd/issue/370/2109

Akyol, H. \& Yıldız, M. (2010). Okuma bozukluğu olan bir öğrencinin okuma ve yazma becerisinin geliştirilmesine yönelik bir durum çalışması. Education Sciences, 5 (4), 1690-1700. Retrieved from https://dergipark.org.tr/tr/pub/nwsaedu/issue/19822/212236

Baker, C. E. (2013). Fathers' and mothers' home literacy involvement and children's cognitive and social emotional development: Implications for family literacy programs. Applied Developmental Science, 17(4), 184-197. DOI:10.1080/10888691.2013.836034

Bakkaloğlu, H. (2013). Ebeveynlerin gözüyle özel gereksinimli çocukların erken müdahaleden okul öncesi programlara geçiş süreci. Eğitim ve Bilim, 38(169), 311-327. Retrieved from http://egitimvebilim.ted.org.tr/index.php/EB/article/view/2284 
Balcı, A. (2013). Sosyal bilimlerde araştırma: yöntem, teknik ve ilkeler. Ankara: Pegem A Publishing.

Başal, M. \& Batu, E. S. (2002). Zihin özürlü öğrencilere okuma yazma öğretme konusunda alt özel sınıf öğretmenlerinin görüş ve önerileri. Ankara Üniversitesi Eğitim Bilimleri Fakültesi Özel Eğitim Dergisi, 3(02), 85-98. DOI: 10.1501/Ozlegt_0000000067

Başkale, H. (2016). Nitel araştırmalarda geçerlik, güvenirlik ve örneklem büyüklüğünün belirlenmesi. Dokuz Eylül Üniversitesi Hemşirelik Fakültesi Elektronik Dergisi, 9(1), 23-28. Retrieved from https://dergipark.org.tr/en/pub/deuhfed/issue/46796/586804

Bayraklı, H. (2016). Okul öncesinde kaynaştırma konulu anne eğitim programının çıktılarının anne ve öğretmen görüşlerine göre değerlendirilmesi: bir karma yöntem araştırması. Unpublished doctoral thesis. Ankara University Institute of Educational Sciences, Ankara.

Büyüköztürk, Ş., Çakmak, E. K., Akgün, Ö. E., Karadeniz, Ş. \& Demirel, F. (2014). Bilimsel araştırma yöntemleri. Ankara: Pegem Academy.

Chard, D. J., Vaughn, S. \& Tyler, B. J. (2002). A synthesis of research on effective interventions for building reading fluency with elementary students with learning disabilities. Journal of learning disabilities, 35(5), 386-406. DOI: 10.1177/00222194020350050101

Çağan, K. (2011). Ailenin İşlevleri. In K. Canatan \& E. Yıldırım (Eds.), Aile sosyolojisi. (pp. 83-97). İstanbul: Açılım Book.

Dadandi, I. \& Dadandi, P. U. (2015). Özgül öğrenme güçlüğü olan öğrencilerin bulunduğu sınıflarda derse giren Türkçe öğretmenlerinin yaşadıkları sorunlara ilişkin görüşleri. Pegem Eğitim ve Öğretim Dergisi, 5(5), 509-532. DOI: 10.14527/pegegog.2015.028

Dağ, N. (2010). Okuma güçlüğünün giderilmesinde 3p metodu ile boşluk tamamlama (cloze) tekniğinin kullanımı üzerine bir çalışma. Ankara Üniversitesi Eğitim Bilimleri Fakültesi Özel Eğitim Dergisi, 11(1), 63-74.

Dam, H. (2008). Öğrencinin okul başarısında aile faktörü. Hitit Üniversitesi Illahiyat Fakültesi Dergisi, 7(14), 75-99. Retrieved from https://dergipark.org.tr/tr/download/article-file/85817

Darling, S. \& Hayes, A. E. (1989). Breaking the cycle of lliteracy: the kenan family literacy model program. The William R. Kenan, Jr. Charitable Trust Family Literacy Project. Final Report. Retrieved from https://files.eric.ed.gov/fulltext/ED324496.pdf

Duran, E. \& Sezgin, B. (2012). Rehberli okuma yönteminin akıcı okumaya etkisi. Gazi Üniversitesi Gazi Eğitim Fakültesi Dergisi, 32(3), 633-655. Retrieved from http://www.gefad.gazi.edu.tr/en/download/articlefile/76924

Dündar, H. \& Akyol, H. (2014). Okuma ve anlama problemlerinin tespiti ve giderilmesine ilişkin örnek olay çalışması. Eğitim ve Bilim, 39(171), 361-377. Retrieved from http://egitimvebilim.ted.org.tr/index.php/EB/article/view/1991/633

Froiland, J. M., Peterson, A. \& Davison, M. L. (2013). The long-term effects of early parent involvement and parent expectation in the USA. School Psychology International, 34(1), 33-50. DOI: $10.1177 / 0143034312454361$

Gersten, R., Fuchs, L. S., Williams, J. P. \& Baker, S. (2001). Teaching reading comprehension strategies to students with learning disabilities: A review of research. Review of educational research, 71(2), 279 320. DOI: $10.3102 / 00346543071002279$

Glesne, C. (2012). Nitel araştırmaya giriş. (trans. A. Ersoy \& P. Yalçinoglu). Ankara: Anı Publishing.

Görgün, B. (2018). Akıcı okuma ve okuduğunu anlama destek eğitim programının (oka²dep) özel öğrenme güçlügü olan öğrencilerin okuma becerilerine etkisi. Unpublished doctoral thesis. Eskişehir Osmangazi University, Institute of Education Sciences, Eskişehir.

Gül, G. (2007). Okuryazarlık sürecinde aile katılımının rolü. Ankara Üniversitesi Eğitim Bilimleri Fakültesi Özel Eğitim Dergisi, 8(01), 17-30. Retrieved from https://dergipark.org.tr/en/download/article-file/159178

Gül, H., Yürümez, E., Gül, A., Kılıç, H. T. \& Günay-Ay, M. (2016). Öğretmenlerin özgül öğrenme güçlüğü ile ilgili bilgi düzeyleri ve damgalama: çok merkezli bir çalışma. Ortadoğu Medical Journal/Ortadoğu Tıp Dergisi, 8(2), 76-82. Retrieved from https://eds.a.ebscohost.com/eds/pdfviewer/pdfviewer?vid= $0 \& s i d=30 c d d 6 b f-9 b 46-45 c 5-a c 17-c 1 b 91083 d 823 \% 40 s d c-v-s e s s m g r 03$

Henderson, A. T. \& Mapp, K. L. (2002). A new wave of evidence: The impact of school, family, and community connections on student achievement. Austin, TX: Southwest Educational Development Laboratory. Retrieved from https://files.eric.ed.gov/fulltext/ED474521.pdf 
Hunt, P., Soto, G., Maier, J. \& Doering, K. (2003). Collaborative teaming to support students at risk and students with severe disabilities in general education classrooms. Exceptional Children, 69(3), 315332. Retrieved from http://www.casenex.com/casenex/cecReadings/collaborativeTeaming.pdf

Johnson, A. P. (2014). Eylem araştırması el kitabı. (trans. Y. Uzuner \& M. Özten- Anay). Ankara: Anı Publishing.

Kardaş İşler, N. \& Şahin, A.E. (2016) Bir ilkokul 4. sınıf öğrencisinin okuma bozukluğu ve anlama güçlüğü: bir durum çalışması. Ana Dili Eğitimi Dergisi, 4(2), 174-186. DOI: 10.16916/aded.23121

Kılıç, F. (2018). Illkokul 1. sınıf velilerine yönelik bir aile okuryazarlığı programı geliştirme çalışması. Unpublished doctoral thesis. Marmara University Institute of Educational Sciences, Istanbul.

Kırcaali-iftar, G. \& Tekin, E. (1997). Tek denekli araştırma yöntemleri. Ankara: Turkish Psychological Association Publications.

Lindberg, E. N. A. (2014). Eğitim fakültesi son sınıf öğrencilerinin aile katılımı ile ilgili görüşleri. Kuram ve Uygulamada Eğitim Bilimleri, 14(4), 1339-1361. DOI: 10.12738/estp.2014.4.1920

MEB, (2008). Özel eğitim ve rehabilitasyon merkezi özel öğrenme güçlüğü destek eğitim programı. Ankara: Publications of the Ministry of National Education

MEB (2018). Türkçe dersi ögretim programı. Ankara: Publications of the Ministry of National Education

Miedel, W. T. \& Reynolds, A. J. (1999). Parent involvement in early intervention for disadvantaged children: Does it matter?. Journal of School Psychology, 37(4), 379-402. Retrieved from https://www.sciencedirect.com/science/article/pii/S0022440599000230?via\%3Dihub

Miles, M. B. \& Huberman, A. M. (1994). Qualitative data analysis: an expanded sourcebook. Thousand Oaks, CA: Sage Publications.

Ornstein, A. C. \& Hunkins, F. P. (1998). Curriculum foundations, principles, and ıssues. Boston: Allyn \& Bacon.

Ölmez, N. (2017). Veli bilgilendirme programının ilk okuma yazma sürecine katkısı hakkındaki veli ve ögrretmen görüşleri. Unpublished master's thesis. Recep Tayyip Erdogan University, Institute of Social Sciences, Rize.

Özel Eğitim Hakkında Kanun Hükmünde Kararname (1997, 30 May). Official Gazette (No: 573).

Özel Eğitim Hizmetleri Yönetmeliği (2018, 7 July). Official Gazette (No: 30471).

Özçelik, İ. (1983). Okuma güçlükleri ve düzeltilmesi. Eğitim ve Bilim, 8(45), 22-27. Retrieved from http://egitimvebilim.ted.org.tr/index.php/EB/article/view/5767

Özen- Altınkaynak, Ş. (2014). Aile temelli okuma yazmaya hazırlık programının çocukların okuma yazmaya hazırlık becerilerine etkisi. Unpublished doctoral thesis, Hacettepe University, Institute of Educational Sciences, Ankara.

Özmen, R. G. (2005). Öğrenme güçlüğü olan öğrencilerin okuma hızlarının metinlerde karşılaştırılması. Eğitim ve Bilim, 30(136), 25-30. Retrieved from http://egitimvebilim.ted.org.tr/index.php/EB/article/view/5189/1337

Özsoy, S. A., Özkahraman, A. G. Ş. \& Çallı, Y. H. F. (2006). Zihinsel engelli çocuk sahibi ailelerin yaşadıkları güçlüklerin incelenmesi. Sosyal Politika Çalışmaları Dergisi, 9(9), 69-78. Retrieved from https://dergipark.org.tr/en/download/article-file/198021

Özyürek, M. (2009). Öğrenme Güçlüğü Olan Çocukların Eğitimi. In G. Akçamete (Eds.), Genel eğitim okullarında özel gereksinimi olan öğrenciler ve özel eğitim (pp. 315-336). Ankara: Kök Publishing.

Patton, M. Q. (2014). Nitel araştırma ve değerlendirme yöntemleri. (trans. M. Bütün \& S. B. Demir). Ankara: Pegem Academy.

Rasinski, T. \& Stevenson, B. (2005). The effects of fast start reading: a fluency-basedhome involvement reading program, on the reading achievement of beginning readers. Reading Psychology, 26(2), 109125. DOI: $10.1080 / 02702710590930483$

Richey, R. C. \& Klein, J. D. (2005). Developmental research methods: creating knowledge from instructional design and development practice. Journal of Computing in Higher Education, 16(2), 23-38. Retrieved from https://link.springer.com/content/pdf/10.1007/BF02961473.pdf

Richey, R. C., Klein, J. D. \& Nelson, W. (2004). Developmental research: Studies of instructional design and development. In D. Jonassen (Eds.), Handbook of research for educational communications and technology (pp. 1099-1130). Mahwah, NJ: Lawrence Erlbaum Associates Publishers. 
Roberts, G., Torgesen, J. K., Boardman, A. \& Scammacca, N. (2008). Evidence-based strategies for reading instruction of older students with learning disabilities. Learning Disabilities Research \& Practice, 23(2), 63-69. Retrieved from https://www.meadowscenter.org/files/resources/robertsetal08.pdf

Rodrıguez-Brown, F. V. (2004). Project flame: a parent support family literacy model. In B. H. Wasik (Eds.) Handbook of family literacy, (pp. 213-299). New York: Routledge.

Sahay, A., Prakash, J., Khaique, A. \& Kumar, P. (2013). Parents of intellectually disabled children: a study of their needs and expectations. International Journal of Humanities and Social Science Invention, 2(7), 1-8. Retrieved from https://fardapaper.ir/mohavaha/uploads/2019/05/Fardapaper-Parents-ofIntellectually-Disabled-Children-A-Study-of-Their-Needs-and-Expectations.pdf

Senechal, M. \& Young, L. (2008). The effect of family literacy interventions on children's acquisition of reading from kindergarten to grade 3: A meta-analytic review. Review of Educational Research, 78(4), 880-907. Retrieved from https://www.jstor.org/stable/pdf/40071148.pdf

Sezgin, Z. Ç. \& Akyol, H. (2015). Okuma güçlüğü olan dördüncü sınıf öğrencisinin okuma becerilerinin geliştirilmesi. Turkish Journal of Education, 4(2), 4-16. DOI: 10.19128/turje.181115

Sorani-Villanueva, S., McMahon, S. D., Crouch, R. \& Keys, C. B. (2014). School problems and solutions for students with disabilities: a qualitative examination. Journal of Prevention \& intervention in The Community, 42(1), 58-71. DOI: 10.1080/10852352.2014.855060

Sönmez, V. \& Alacapınar, F. G. (2011). Örneklendirilmiş bilimsel araştırma yöntemleri. Ankara: Anı Publishing.

Sucuoğlu, B. (1996). Kaynaştırma programlarında anne baba katılımı. Ankara Üniversitesi Eğitim Bilimleri Fakültesi Özel Eğitim Dergisi, 2(02), 25-43. Retrieved from https://dergipark.org.tr/en/download/article-file/159256

Şanlı, E. (2012). Özel eğitim ve rehabilitasyon merkezlerine devam eden zihin engelli çocuğu olan ailelerin gereksinimlerinin belirlenmesi. Unpublished master's thesis. Ondokuz Mayıs University, Institute of Educational Sciences, Samsun.

Tavil, Y. Z. \& Karasu, N. (2013). Aile eğitim çalışmaları: Bir gözden geçirme ve meta-analiz örneği. Eğitim ve Bilim, 38(168), 85-95. Retrieved from https://eds.a.ebscohost.com/eds/pdfviewer/ pdfviewer?vid=0\&sid=a25b78c3-82f3-42ea-bffc-cad4eb85c648\%40sdc-v-sessmgr01

Tekinarslan, İ. Ç., Sivrikaya, T., Keskin, N. K., Özlü, Ö. \& Rasmussen, M. U. (2018). Kaynaştırma eğitimi alan öğrencilerin ebeveynlerinin gereksinimlerinin belirlenmesi. ilköğretim Online, 17(1), 82-101. DOI: 10.17051/ilkonline.2018.413746

Toprakçı, E. (2017). Sınıf Yönetimi. Ankara: Pegem Akademi Yayınları

Uçar-Rasmussen, M. \& Cora-İnce, N. (2017). Özel öğrenme güçlüğü olan bireylere üstbilişsel okuduğunu anlama stratejilerinin öğretiminde sesli düşünme yönteminin etkililiği. Abant İzzet Baysal Üniversitesi Eğitim Fakültesi Dergisi, 17(4), 2180-2201. DOI: 10.17240/aibuefd.2017.17.32772-364006

Uçgun, D. (2003). Türkçe öğretimi açısından özel öğrenme güçlüğü. Türklük Bilimi Araştırmaları, 13(13), 203-217. Retrieved from https://dergipark.org.tr/en/download/article-file/156768

Uluğtekin, S., Cılga, İ. \& Sunay, İ. L. (2002). Çoğulcu demokratik toplum için aile eğitimi projesi. Sosyal Politika Çalışmaları Dergisi, 2(5), 27-31. Retrieved from https://dergipark.org.tr/en/download/articlefile/198052

Varış, F. (1969). Eğitimde program araştırmaları. Ankara Üniversitesi Eğitim Bilimleri Fakültesi Dergisi, 2(1), 23-32. Retrieved from https://dergipark.org.tr/tr/pub/auebfd/archive

Yıldırım, A. \& Şimşek, H. (2013). Sosyal bilimlerde nitel araştırma yöntemleri. Ankara: Seçkin Publishing.

Yıldız, M. (2013). Yazma güçlüğü (disgrafi) olan bir ilkokul 2. Sınıf öğrencisinin el yazısı okunaklıığının geliştirilmesi: eylem araştırması. Uşak Üniversitesi Sosyal Bilimler Dergisi, 6(4), 281-310. Retrieved from https://dergipark.org.tr/tr/pub/usaksosbil/issue/21640/232604 


\section{Özel Öğrenme Güçlüğü Yaşayan Çocuklarun Okuma Yazma Eğitimine Anne Katılumı: Bir Eğitim Programı Taslağı²}

\author{
Dr. Öğr. Üyesi Didem Kayahan Yüksel \\ Cumhuriyet Üniversitesi- Türkiye \\ ORCID: 0000-0002-0184-6070 \\ didemkayahan@cumhuriyet.edu.tr
}

\author{
Doç. Dr. Esma Emmioğlu Sarıkaya \\ Gaziosmanpaşa Üniversitesi- Türkiye \\ ORCID: 0000-0002-6188-7173 \\ esma.emmioglu@gop.edu.tr
}

\begin{abstract}
Özet
Bu çalışmanın amacı, özel öğrenme güçlüğü olan çocukların okuma yazma eğitimi sürecine annelerin katılımını desteklemek için annelere yönelik bir taslak eğitim programı önermek ve taslak programı uygulayarak uygulamanın sonuçlarını incelemektir. Program geliştirme araştırması olarak tasarlanan çalışmada görüşme, gözlem, araştırmacı günlügü gibi nitel veri toplama yöntemleri kullanılmıştır. Araştırmanın katılımcıları amaçlı örnekleme yöntemlerinden ölçüt örnekleme kullanılarak belirlenmiş olup, özel öğrenme güçlüğü olan dört çocuk anneleri ve öğretmenleridir. Elde edilen verilerin analizinde MAXQDA nitel veri analiz programı kullanılarak betimsel analiz yapılmıştır. Çalışmada geçerliliği ve güvenirliği sağlamak amacıla; veri çeşitlemesi, uzman incelemesi, uzun süreli etkileşim, amaçlı örnekleme ve ayrıntılı betimleme yöntemleri kullanılmıştır. Anne eğitim programı taslağı içerik olarak özel öğrenme güçlüğ̈̈, öğretim ilkeleri, okur-yazarlık, okuma yazmaya hazırlık ve ses temelli cümle yöntemi konularını içermektedir. Program taslağında ayrıca ilgili kazanımlar, eğitim durumları ve değerlendirme öğeleri bulunmaktadır. Anne eğitim programı taslağında ağırlıklı olarak sunuş yoluyla öğretim stratejisi benimsenmiş olup; soru-cevap, tartışma, anlatım, örnek olay, rol oynama gibi öğretim yöntemleri kullanılmıştır. Programın değerlendirme öğesinde ise süreç ve toplam değerlendirme etkinliklerine yer verilmiştir. Programda her bir öğretim oturumunun sonunda; açık uçlu sorular, boşluk doldurma, doğru-yanlış işaretleme, balık kılçığı, tanılayıcı dallanmış ağaç, öz değerlendirme, gözlem formları gibi değerlendirme etkinlikleri bulunmaktadır. Araştırmada yer alan katılımcı ifadelerinden hareketle anne eğitim programı taslağl; Annelerin öğretmenle iş birliği yapma, çocuk ve öğretmenle daha iyi iletişim kurma, çocuğuna evde ödev/tekrar yaptırma konularında olumlu katkıları olduğu düşünülmektedir. Ayrıca katılımcı öğretmenler, annelerin ve çocukların motivasyonlarında olumlu değişimler olduğunu, annelerin çocuklarının eğitiminde daha aktif rol ve sorumluluk aldıklarını belirtmişlerdir. Gözlem bulgularına dayalı olarak taslak anne eğitim programının anne-çocuk okuma yazma çalışmalarına olumlu yansımaları olduğu düşünülmektedir.
\end{abstract}

Anahtar Kelimeler: Eğitim Programı Taslağı, Ailenin Eğitime Katılımı, Okuma Yazma Eğitimi, Anne Eğitimi, Özel Öğrenme Güçlüğü.

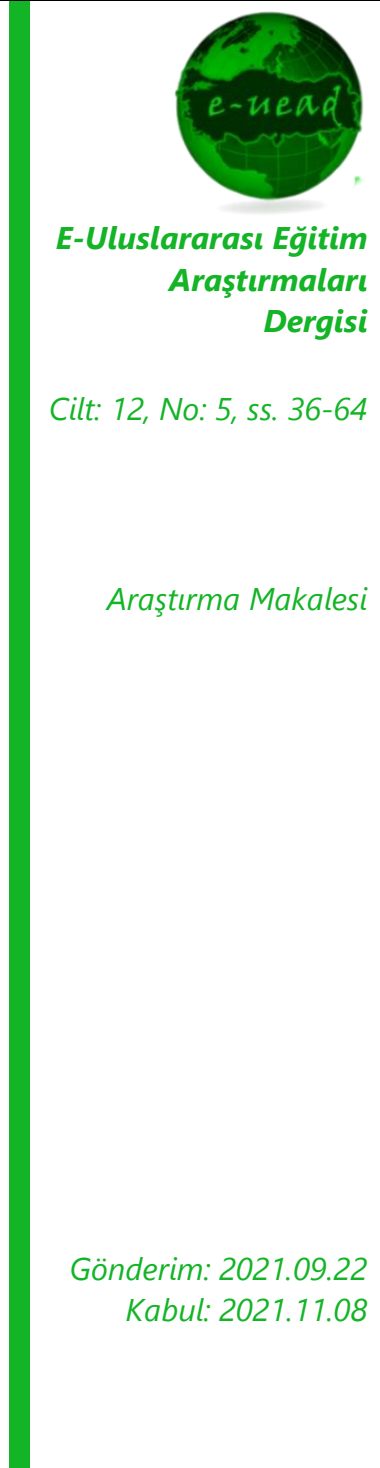

\section{Önerilen Atıf}

Kayahan- Yüksel, D. \& Emmioğlu- Sarıkaya, E. (2021). Mother's participation in literacy education of children with special learning disability: a draft training program, E-Uluslararası Eğitim Araştırmaları Dergisi, 12(5), 36-64. DOI: https://doi.org/10.19160/19160/e-ijer.999351

\footnotetext{
${ }^{2}$ Bu araştırma, birinci yazarın ikinci yazarın danışmanlığında hazırladığı "Özel Öğrenme Güçlüğü Yaşayan Çocukların Okuma Yazma Eğitimine Anne Katııımı: Bir Eğitim Programı Taslağı" başıklı doktora tezinden üretilmiştir.
} 


\section{Genişletilmiş Özet}

Giriş: Okuma ve yazma becerileri temel akademik beceriler arasındadır. Yaşıtları ile aynı anda okuma yazma öğrenemeyen çocuklar, hem akademik hem de sosyal davranışlar açısından bazı yetersizlikler yaşayabilmektedirler. Özel ögrrenme güçlügü olan çocuklar, başta Türkçe olmak üzere birçok derse iliş̧kin becerileri öğrenmekte zorlanabilmektedirler. Bu nedenlerle özel öğrenme güçlügü olan çocukların eğitimlerinde sık tekrarlara ve aile desteğine ihtiyaç duyulmaktadır. Özel eğitim bir ekip işidir ve aile bu ekibin aktif bir parçası olmak durumundadır. Özellikle kaynaştırma eğitimine katılan bir çocuğa sınıf ögretmenin günlük olarak ayırabileceği zaman kısıtlıdır. Bu durumda ailenin çocuğunun eğitimine katılması bir ihtiyaçtır (Başal ve Batu, 2002). Ebeveynlerin çocuğa doğru yardımda bulunabilmesi için okuma yazma yöntem ve teknikleri hakkında bilgi sahibi olmaları gereklidir (Gül, 2007). Sını öğretmenleri zaman zaman ailelere çocuklarının eğitimine katılımı ile ilgili bilgi ve becerileri sözel veya yazılı materyaller yoluyla sunmaktadır. Ancak bir program dahilinde hazırlanıp uygulanmayan eğitimler yetersiz kalmaktadır. Aileye sunulan bu eğitim hizmetlerinin bir program dahilinde sunulması gerekmektedir.

Aileler, çocuğun eğitimine katılma konusunda cesaretlendirilmelidir. Ancak aileler zaman zaman çocuğun eğitimine katılımıyla ilgili yetersiz bilgilere sahip olabilmektedir. Bu durumlarda ailenin eğitime katılımını sağlayıc aile eğitimlerinin düzenlenmesi gerekmektedir. Aile eğitimi özel gereksinimli bireylerin eğitiminde kullanılan en önemli destektir (Tavil ve Karasu, 2013). Ancak aile eğitiminden yeterli verimin alınabilmesi için aileye kazandırılmak istenen bilgi ve becerilerin bir program dahilinde uygulanması gerekmektedir. Herhangi bir formal eğitim sürecinden bekleneceği üzere, ailelere sunulacak eğitimlerin de belirli bir program dâhilinde yapılması gereklidir. Bu çalışmada özel öğrenme güçlügü yaşayan çocukların okuma yazma eğitim sürecine annelerin katıımının desteklenmesi amacıyla annelere yönelik bir eğitim programı taslağı önerilmiş ve taslak programı uygulayarak, uygulama sonuçları incelenmiştir. Çalışmada, çocukla en çok zaman geçiren ebeveyn olan anne ile özel öğrenme güçlüğü yaşayan çocuğunun birlikte daha doğru ve planlı okuma yazma çalışmaları yapmaları hedeflenmiştir. Anne çocuğunun okuma yazma eğitimine katılımda program boyunca edindiği bilgi ve becerileri kullanarak çocuğunun okuma yazma konusundaki ödevlerini daha doğru bir şekilde yaptıracak ve çocuğunun o gün okulda işlediği konuları tekrar ettirebilecektir. Bu yolla çocuğun okuma yazma becerisine olumlu katkılarının olması beklenmektedir.

Yöntem: Bu çalışmanın amacı, özel öğrenme güçlüğ̈̈ yaşayan çocukların okuma yazma eğitim sürecine annelerin katılımının desteklenmesi amacıyla annelere yönelik bir eğitim programı taslağı önermek ve taslak programı uygulayarak, uygulama sonuçlarını incelemektir. Program geliştirme araştırması olarak tasarlanan çalışmada görüşme, gözlem, araştırmacı günlügü gibi nitel veri toplama yöntemleri kullanılmıştır. Çalışmada veri toplamak amacıyla araştırmacı tarafından geliştirilen; anne görüşme formu, ögretmen görüşme formu, gözlem formu ve oturum sonu değerlendirme formu kullanılmıştır. Çalışmanın katılımcıları amaçlı örneklem yöntemlerinden ölçüt örnekleme kullanılarak belirlenmiş olup katılımcılar; özel öğrenme güçlügü yaşayan dört çocuk, bu çocukların anneleri ve öğretmenleridir. Çalışma iç Anadolu Bölgesinde bulunan bir il merkezinde faaliyet gösteren bir özel eğitim kurumunda gerçekleştirilmiştir. Çalışma dokuz aşamada gerçekleştirilmiştir. Çalışmada öncelikle literatür taraması yapılmış ve ailelerin okuma-yazma sürecine katılımının ve özel öğrenme güçlügü yaşayan çocukların eğitimlerinde aile katılımının vurgulandığı görülmüşsür (Akyol \& Yıldız, 2010; Dadandi \& Dadandi, 2005; Dam, 2008; Duran \& Sezgin, 2012; Froiland, Peterson, \& Davison, 2013; Gül, 2007; Gül, Yürümez, Gül, Kılıç \& Günay-Ay, 2016; Miedel \& Reynolds, 1999; Özyürek, 2009; Rasinski \& Stevenson, 2005; Uçgun, 2003). Daha sonra araştırmada kullanılacak ölçme araçları (görüşme formları, gözlem formu ve oturum sonu değerlendirme formu) araştırmacı tarafından geliştirilmiștir. Ardından ilgili literatür incelenerek okuma yazma eğitim sürecinde anne eğitim programı taslağının hedef, içerik, eğitim durumu ve değerlendirme öğelerinin hazırlanması işlemleri yapılmışıı ve ilk taslak olarak önerilen programın ön uygulaması yapılmıştır. Ön uygulamaya bir anne, bu annenin özel öğrenme güçlügü yaşayan 
çocuğu ve çocuğun öğretmeni katılmıştır. Ön uygulamadan elde edilen bulgular ışığında programın ilk taslağında değişiklikler yapılmıştır. Bir sonraki aşamada değişiklikler yapılan anne eğitim programı taslağının uygulanmasına katılacak annelerin seçimi ve seçilen katılımcıların anne çocuk okuma yazma çalışmalarının gözlenmesi işlemleri yapılmıştır. Daha sonra anne eğitim programı taslağı çalışmaya katılan anneler ile uygulanmıştır. Programın uygulanış sürecinde her bir öğretim oturumun tamamlanmasının ardından annelere oturum sonu değerlendirme formları sunularak bu formları o gün katıldıkları eğitimi göz önünde bulunduracak şekilde doldurmaları istenmiştir. Son aşamada ise uygulamaya yönelik olarak annelerle ve öğretmenlerle uygulama sonrası görüşmelerinin yapılması, anne-çocuk okuma yazma çalışmalarının gözlemlenmesi işlemleri yapılmış ve sonuçlar raporlaştırılmıştır. Elde edilen verilerin analizinde, MAXQDA nitel veri analizi programı kullanılarak betimsel analiz yapılmıştır. Çalışmada geçerliliği ve güvenirliği sağlamak amacılla; veri çeşitlemesi, uzman incelemesi, uzun süreli etkileşim, amaçlı örnekleme ve ayrıntılı betimleme yöntemleri kullanılmıştır.

Sonuç: Program geliştirme araştırmalarını diğer araştırmalardan ayıran en önemli özelliklerinden biri araştırmanın sonunda bir model veya sistem önermesidir. Bu bağlamda bu program geliştirme araştırmasının en önemli sonuçlarından biri de anne eğitim program taslağıdır. Bu çalışmada öncelikle konu alanına dayalı olarak anne eğitim programı taslağı hazırlanmış ve bu ilk taslak programın ön uygulaması yapılmıştır. Ön uygulamadan elde edilen bulgular ışı̆ında programın ilk taslağında değişiklikler yapılarak anne eğitim programı taslağına son hali verilmişstir. Anne eğitim programı taslağında; özel öğrenme güçlüğü, öğretim ilkeleri, okur-yazarlık, okuma-yazmaya hazırlık ve okuma-yazma öğretimine ilişkin kazanımlar bulunmaktadır. Programda bilişsel ve duyuşsal alanda kazanımlar yer almaktadır. Programın içerik öğesi oluşturulurken modüler programlama yaklaşımı benimsenmiştir. Eğitim programı içinde yer alan her bir öğrenme ünitesi kendi içinde bütünlük oluştururken diğer öğrenme ünitelerinden bağımsız özellik göstermektedir. içerik düzenlenirken; hayatilik, kendi kendine yeterlilik, anlamlılı, geçerlilik, ilgililik, yararlılk, öğrenilebilirlik ilkeleri göz önünde bulundurulmuştur. Içerik öğeleri somuttan soyuta, basitten karmaşı̆ga, kolaydan zora, bilinenden bilinmeyene ve yakın çevreden uzak çevreye olacak şekilde düzenlenmiştir. Programın içeriği; özel öğrenme güçlügü̈, öğretim ilkeleri, okur-yazarlık, okumayazmaya hazırlık ve ses temelli cümle yöntemi ile okuma yazma ögretimi olmak üzere beş ögrenme ünitesinden oluşmaktadır. Programda baskın olan öğretim yaklaşımı sunuş yoluyla öğretim stratejisidir. Buna göre, içerik genelden özele doğru hiyerarşik bir şekilde öğretmen tarafından sunulmaktadır. Ders planlarının giriş kısmında; dikkat çekme, güdüleme ve hedeften haberdar etmeye yönelik etkinlikler bulunmaktadır. Dersin gelişme kısmında aktif katıım, ilişki kurma, uygulama yapma, dönüt-düzeltme verme işe koşulmuştur. Ders planlarının sonuç kısmında ise çeşitli değerlendirme etkinlikleri bulunmaktadır. Anne eğitim programı taslağının öğrenme-öğretme sürecinde anlatım, soru-cevap, tartışma, rol oynama, örnek olay gibi yöntemler kullanılmıştır. Bu şekilde farklı öğretim yöntemleri kullanılarak, öğrenen rolünü üstlenen annelerin mümkün olduğunca sürece zihinsel ve fiziksel olarak aktif katılımının sağlanması ve yaparak-yaşayarak ögrenmeleri hedeflenmiştir. Programda süreç değerlendirme ve toplam değerlendirme etkinliklerine yer verilmiştir. Programın uygulanış sürecinde etkileşimli bir yaklaşım benimsenmiş olup soru-cevap ve tartışma şeklinde değerlendirmeler yapılmaktadır. Katılımcılardan alınan cevaplar doğrultusunda anında dönüt ve düzeltme verilmektedir. Programda her bir dersin sonunda açık uçlu sorular, boşluk doldurma, doğru-yanlış işaretleme vb. değerlendirme etkinlikleri bulunmaktadır. Ayrıca alternatif değerlendirme tekniklerinden olan; balık kılçı̆̆ı, tanılayıcı dallanmış ağaç, öz değerlendirme, gözlem formları ve tutum ölçekleri kullanılmaktadır. Programın uygulanma sürecinin tamamlanmasının ardından ise gözlem formu aracılığ ile toplam değerlendirme yapılmaktadır.

Çalışmada katılıma ifadelerine dayalı olarak anne eğitim programı taslağının; annelerin öğretmenle işbirliği sağlaması, çocukla ve öğretmenle daha iyi iletişim kurması ve evde çocuğuna ödev/tekrar yaptırması açısından olumlu katkılarının olduğu düşünülmektedir. Ayrıca katılıma ögretmenler annelerin ve çocukların motivasyonlarında olumlu değişimler olduğu ve annelerin çocuğunun eğitiminde daha aktif rol ve sorumluluk aldığı yönünde görüş bildirmiştir. Gözlem 
bulgularından hareketle anne eğitim programı taslağının anne çocuk birlikte yapılan okuma yazma çalışmalarına olumlu yansımaları olduğu düşünülmektedir.

Öneriler: Çalışmadan elde edilen bulgulara dayanarak öğretmenlere yönelik olarak aile ile iletişim ve işbirliği konusunda hizmet içi eğitimler düzenlenebilir. Öğretmenler iletişim ve işbirliği sağlama konusunda aileleri cesaretlendirebilir ve aileleri farklı iletişim kurma teknikleri konusunda bilgilendirebilir. Ayrıca okur-yazarlığı olmayan annelere yönelik olarak öncelikle annelerin okuma yazma becerisini kazanması ve daha sonra çocuğunun okuma yazma eğitimine katılması hususunda anne eğitim programı geliştirme çalışmaları yapılabilir. Bu çalışmada anne eğitim programı taslağının annenin okuma yazma eğitimi sürecine katılımına olumlu yansımaları olduğu tespit edilmiştir. Bu bulgudan hareketle özel öğrenme güçlüğü olan çocukların eğitimine katılımını sağlamak için farklı aile eğitim programları geliştirilebilir ve etkileri araştırılabilir. 